\title{
The Pleistocene prehistory of the Lake Victoria basin
}

Christian A. Tryon ${ }^{a}$ *, J. Tyler Faith ${ }^{b}$, Daniel J. Peppe ${ }^{c}$, Emily J. Beverly ${ }^{c}$, Nick Blegen ${ }^{d}$, Scott Blumenthal ${ }^{e}$, Kendra Chritz ${ }^{f}$, Steve Driese ${ }^{c}$, David Patterson ${ }^{g}$, Warren Sharp ${ }^{h}$

${ }^{a}$ Harvard University, Department of Anthropology, Peabody Museum of Archaeology and Ethnology, 11 Divinity Ave., Cambridge, MA 02138, USA. Email: christiantryon@fas.harvard.edu

${ }^{\mathrm{b}}$ University of Queensland, School of Social Science, Brisbane, QLD 4072, Australia.

${ }^{c}$ Baylor University, Department of Geology, Terrestrial Paleoclimatology Research Group, Waco, TX 76798, USA.

${ }^{\mathrm{d}}$ University of Connecticut, Department of Anthropology, Storrs, CT 06269, USA

${ }^{\mathrm{e}}$ City University of New York, Department of Anthropology, The Graduate Center, New York, NY 10016, USA.

${ }^{\mathrm{f}}$ University of Utah, Department of Biology, Salt Lake City, UT 84112, USA.

${ }^{\mathrm{g}}$ The George Washington University, Center for the Advanced Study of Hominid Paleobiology, Department of Anthropology, Washington, DC 20052, USA.

h Berkeley Geochronology Center, 2455 Ridge Rd., Berkeley, CA94709.

* Corresponding author

\section{Abstract:}

Late Pleistocene sedimentary, biogeochemical, and fossil data from the Lake Victoria basin (the largest lake in Africa) suggest that its reduction or desiccation during periods 
of increased aridity repeatedly facilitated the dispersal of $\mathrm{C}_{4}$ grassland ecosystems across the basin. Archaeological evidence from Middle Stone Age and Later Stone Age sites suggest that human groups diffused into the basin during intervals of declining lake levels, likely tracking the movement of the dense and predictable resources of shoreline environments as well as the dense but less predictable $\mathrm{C}_{4}$ grass grazing herbivores. Repeated cycles of lake expansion and contraction provide a push-pull mechanism for the isolation and combination of populations in Equatorial Africa that may contribute to observed Late Pleistocene human biological variability suggested by the fossil and genetic records. Latitudinal differences in the timing of environmental change between the Lake Victoria basin and surrounding regions may have promoted movements across, within, and possibly out of Africa.

Keywords: Middle Stone Age, Later Stone Age, paleoenvironment, human dispersals

\section{Introduction}

A suite of genetic, skeletal, and archaeological lines of evidence suggest multiple dispersals of populations of Homo sapiens across and out of Africa during the Late Pleistocene ( 126-12 ka), but the mechanisms driving these dispersals remain poorly understood. Modern humans (Homo sapiens) first appeared in Africa, with the oldest fossil remains dating to $195 \mathrm{ka}$ (McDougall et al., 2005; Brown et al., 2012). Since their origins, dispersed populations accumulated substantial morphological, genetic, and cultural variability (Lahr and Foley, 1998; McBrearty and Brooks, 2000; Crevecoeur et al., 2009; Gunz et al., 2009; Harvati et al., 2011; Pearson, 2013; Campbell et al., 2014; Tryon et al., 2015). Subsequent Late Pleistocene dispersals out of Africa sampled only a small portion of that original variability (e.g., von Cramon-Taubadel and Lycett, 2008; Soares et al., 2012; Rito et al., 2013). As H. sapiens replaced all other hominin taxa during their global expansion, investigating Late Pleistocene behavioral variability in Africa and how it formed is therefore essential to understanding the evolutionary success of our species. Our goal here is to examine the environmental basis for some of this variability in Equatorial Africa, specifically the impact of the contraction and expansion of Lake Victoria as a push-pull mechanism for the diffusion of populations into and out

of the region (for similar investigations elsewhere in Africa, see Kingdon, 1989; Lahr and 
Foley, 1998; Cowling et al., 2008; Trauth et al., 2010; Blome et al., 2012; Mackay et al., 2014; Scerri et al., 2014; Faith et al., 2015).

To reconstruct Pleistocene environments, we synthesize the available geological, ecological, and fossil records for the Lake Victoria basin (Figure 1), based in part on our own fieldwork in the region, which began in 2009. We develop a model for forager responses to lake level flux, and test aspects of the model against the archaeological record from two Late Pleistocene time intervals. We focus on two periods of increased aridity during which Lake Victoria was desiccated or substantially reduced: (1) a younger period that follows the Last Glacial Maximum (LGM, 19-26.5 ka; Clark et al., 2009) associated with a Later Stone Age (LSA) archaeological record; and (2) an older period that follows the end of the peak of the Last Interglacial ( 125 ka), and spans from 100$35 \mathrm{ka}$, associated with a Middle Stone Age (MSA) archaeological record. The younger of these two intervals (informally referred to throughout as the lateglacial interval) contains well-dated environmental and archaeological records spanning $~ 7.5 \mathrm{kyr}$ that may sample a period characterized by substantial human biological variability no longer present in extant populations (Tryon et al., 2015). The older interval (referred to throughout as the $\sim 100-35 \mathrm{ka}$ interval) spans $\sim 65 \mathrm{ky}$ and has comparatively reduced temporal resolution, but overlaps with the estimated timing of major movements of populations of modern humans across and subsequently out of Africa (e.g., Mellars, 2006; Rose et al., 2011; Soares et al., 2012; Rito et al., 2013)

\section{Lake Victoria}

Lake Victoria straddles the Equator from $\sim 0.5^{\circ} \mathrm{N}-3.0^{\circ} \mathrm{S}$ and lies in the trough between the eastern and western branches of the East African Rift Valley System (EARS) (Chorowicz, 2005) (Figure 1). The lake formed during the last $\geq 400 \mathrm{ka}$, as continued but intermittent uplift of the western branch of the EARS caused the back-ponding and reversal of formerly westward-flowing streams that once crossed the basin (Temple, 1966; Bishop, 1969; Danley et al., 2012). A number of the buried channels of these streams can still be traced across the lake floor (Figure 1). With a surface area of 68,800 $\mathrm{km}^{2}$, Lake Victoria is the largest tropical lake in the world and the largest lake in Africa 
(Crul, 1995), and is thus today a defining geographic feature of Equatorial Africa. It is large enough to generate its own weather system (Thiery et al., 2015) and supports some of the most densely settled areas of human occupation in sub-Saharan Africa (Nelson, 2004). Vegetation around the lake today includes predominantly $C_{3}$ bushland, thicket, and forest comprising a mosaic of taxa endemic to surrounding regions (White, 1983), a combination that may result from Pleistocene biome expansions (Kingdon, 1989; Cowling et al., 2008; Linder et al., 2012; Faith et al., 2015), with significant ecological restructuring occurring as recently as the last few millennia (Chritz et al., 2015). The lake also sits at the junction between central African forests to the west and savanna habitats to the east and forms an important boundary for large mammal populations, with forest species including red river hog (Potamochoerus porcus), okapi (Okapia johnstoni), and chimpanzee (Pan troglodytes) found to the west and savanna species, including wildebeest (Connochaetes taurinus), zebra (Equus quagga), and warthog (Phacochoerus aethiopicus) to the east.

Because average rainfall over the rainfall is almost equal to average evaporation, modern Lake Victoria is very sensitive to changes in precipitation (Piper et al., 1986; Sutcliffe and Petersen, 2007). Moisture is primarily delivered from the Indian Ocean via southeasterly winds (Nicholson, 1996). The mean annual precipitation varies spatially but is on average 1200-1600 mm/year over the catchment area (Piper et al., 1986; Crul, 1995; Yin and Nicholson, 1998). About $80 \%$ of the inflow to the lake is direct input from recycled lake water with $\sim 20 \%$ contributed by tributaries (Yin and Nicholson, 1998; Sutcliffe and Petersen, 2007). The Kagera River (Figure 1) is the largest tributary ( 10\% of total inflow) and drains the highlands of Rwanda and Burundi to the west (Shahin, 1985; Yin and Nicholson, 1998). Outflow is to the north at Jinja, where Lake Victoria serves as a primary source of the Nile (Figure 1). Although large, the lake is shallow, with a current maximum depth of $~ 68 \mathrm{~m}$ (Johnson et al., 1996), leading E.J. Wayland (Wayland, 1928), the first scholar dedicated to the study of the history of Lake Victoria, to refer to it as "nothing but a titanic puddle." As a result of this geometry, large changes in lake surface area can occur with modest changes in depth. Because local precipitation is derived primarily from the lake itself, Lake Victoria expands and contracts in response 
to changes in rainfall availability (Broecker et al., 1998; Yin and Nicholson, 1998; Milly, 1999; Bootsma and Hecky, 2003). Historical fluctuations of $~ 4 \mathrm{~m}$ have been documented during the $19^{\text {th }}$ century (Nicholson, 1998) and can be linked to changes in precipitation (Kite, 1981, 1982; Sene and Plinston, 1994).

Several sedimentary features attest to the scale of these past fluctuations in lake level. Evidence for increases in lake level following formation of the modern lake basin includes wave-cut terraces and horizontally bedded beach deposits about the circumference of the lake at $+3,+10-12$, and $+18 \mathrm{~m}$ above present water level (Doornkamp and Temple, 1966; Temple, 1966). The $+3 \mathrm{~m}$ beach deposit is dated to 4 ka (Bishop, 1969); the others are currently undated. Eight sediment cores from across Lake Victoria (Figure 1), including ones from the deepest portion of the basin, preserve all or part of a $>1$-m-thick soil (interpreted as a paleo-vertisol) that formed during complete desiccation of the lake $\sim 17-16 \mathrm{ka}$, with a second, thinner paleo-vertisol dated to 15-14 ka visible in the Ibis-1 ('Damba Channel') and V95-2P cores (Kendall, 1969; Talbot and Livingstone, 1989; Johnson et al., 1998; Talbot and Laerdal, 2000; Stager and Johnson, 2008; Stager et al., 2011). Seismic surveys across the lake show four basinwide unconformities in the subsurface sedimentary record (Johnson et al., 1996). The uppermost is correlated with the $\sim 17-16$ ka desiccation event (the $\sim 15-14$ ka desiccation event is not readily distinguished in the seismic data). This suggests at least three additional major desiccation events in the history of Lake Victoria. These older desiccation events are undated and of unknown duration, although (Stager and Johnson, 2008) speculate an age of $\sim 80 \mathrm{ka}$ for the surface underlying the $\sim 17-16 \mathrm{ka}$ paleosol based on inferred sedimentation rates.

\section{The environmental record}

\subsection{The lateglacial history of Lake Victoria}

Cores V95-1p, V95-2p, V95-3p, V95-6p, V96-7p, P-2, Ibis-1, Ibis-3 (Figure 1) provide the most detailed record of the history of Lake Victoria since desiccation at $\sim 17-16 \mathrm{ka}$, sample a large spatial extent of the lake, and include the deepest portions of the basin (Kendall, 1969; Stager, 1984; Talbot and Livingstone, 1989; Johnson et al., 1996; 
Johnson et al., 1998; Beuning, 1999; Talbot and Laerdal, 2000; Stager and Johnson, 2008; Stager et al., 2011; Berke et al., 2012). These cores sample one or two soil horizons (paleosols) or other surfaces (e.g., shell lag deposits) that indicate multiple intervals of changes in the lake's shoreline position and water depth. Radiocarbon dates on sediments and plant remains from beneath, within, and above the paleosols, as well as on mollusk shells marking a former near-shore lag-deposit in the Ibis-1 core provide the $\sim 17-16 \mathrm{ka}$ age for that desiccation event. The overlying and less prominent $\sim 15-14 \mathrm{ka}$ desiccation surface is recorded in cores V95-2P and the Ibis-1 core (Stager et al., 2011). Both desiccation events have been linked to climatic changes that resulted in a reduction in moisture availability, with the $17-16$ ka surface tied to Heinrich Event 1 (Stager et al., 2011). Bonnefille and Chalie (2000) estimate a $\sim 42-45 \%$ reduction in mean annual precipitation for the LGM and lateglacial based on pollen data from cores in the Rwanda, Burundi, and Democratic Republic of the Congo highlands at the headwaters of streams that feed into Lake Victoria, broadly consistent with water balance models for Lake Victoria that suggest that a 50-75\% reduction in precipitation could reduce the surface of area of Lake Victoria to <10\% of its present size (Broecker et al., 1998; Milly, 1999).

The 17-16 ka soil in the basal sediments exposed in the V95-2P and Ibis-1 cores (the best described cores) consists of greenish-black crumbly muds with vertical cracks, sand grains, rootlet traces and small diffuse carbonate nodules that are interpreted as a paleovertisol that formed on muddy lake flats sub-aerially exposed during lake desiccation (Talbot and Laerdal, 2000; Stager et al., 2011), typical of soils forming on exposed lake beds in eastern Africa today (Ahmad, 1996). Fragments of terrestrial plant debris are abundant, as are well-preserved grass cuticles showing typical $\mathrm{C}_{4}$ cell morphology. The presence of grasses is consistent with soil $\delta^{13} \mathrm{C}$ values of $>-20 \%$ that indicate significant $\mathrm{C}_{4}$ biomass (Talbot and Livingstone, 1989; Talbot and Laerdal, 2000), although ${ }^{13} \mathrm{C}$ enriched values in aquatic ecosystems can also reflect $\mathrm{C}_{3}$ algal photosynthesis using bicarbonate to assimilate carbon (Farquhar et al., 1989). Pollen records from the V95-2P and P-2 cores show abundant ( 40-50\%) grass (Poaceae) pollen indicating extensive grasses in the area during lake lowstand (Kendall, 1969; Beuning, 1999), with moderateto-large amounts ( 15-40\%) of sedge (Cyperaceae) such as papyrus (Cyperus papyrus) 
found in the Lake Victoria region today and perhaps bulrush (Typha), common throughout East Africa (Lind and Morrison, 1974). These sedges suggest the presence of at least seasonally available bodies of standing water (e.g., as springs, seeps, swamps, small ponds or streams).

The V95-2P basal Vertisol is overlain by a thin layer (15-cm-thick) of diatomaceous muds that reflect a brief return to lacustrine conditions for perhaps $10^{2}-10^{3}$ years prior to the second desiccation event $\sim 15-14 \mathrm{ka}$; shell lag deposits in the Ibis-1 core similarly reflect a major shift in the lake shoreline position during this time (Stager, 1984; Talbot and Laerdal, 2000; Stager and Johnson, 2008; Stager et al., 2011). The second paleoVertisol is not recognized in most of the collected cores. This is likely a reflection of the 10-cm sampling interval used to study the cores as well as varied sedimentation rates, such that the thin mud layer that distinguishes the upper and lower soils may either have been missed or may well be absent from some areas (Talbot and Laerdal, 2000). Isotopic and plant macrofossil data also suggest a $\mathrm{C}_{4}$ grassland-dominated environment for the upper $~ 15-14$ ka paleosol. The carbon isotopic composition of leaf wax biomarkers from core V95-1P demonstrates that $\mathrm{C}_{4}$ plants comprised the majority of terrestrial vegetation within the lake catchment from $\sim 15-1$ ka (Berke et al., 2012). Sediments overlying the second paleosol indicate a rapid flooding of the basin and at the V95-2P core site, and pollen data from the core indicate the persistence of sedges (e.g., C. papyrus) such as those that now fringe much of the lake (Lind and Morrison, 1974). Lake Victoria subsequently filled to a depth near that of today, a level it has likely not fallen below since $\sim 13 \mathrm{ka}$, with overflow via the Victoria Nile occurring by the onset of the Holocene (Kendall, 1969; Beuning, 1999; Johnson et al., 2000; Talbot and Laerdal, 2000; Talbot et al., 2000; Beuning et al., 2002). During the Holocene, the pollen record becomes increasingly dominated by the fig family (Moraceae), indicating the formation of fringing forests with the return to humid conditions (Kendall, 1969; Beuning, 1999), with increased humidity during the Holocene also reported from the Rawanda and Burundi highlands at the margins of the Lake Victoria basin (Bonnefille and Chalie, 2000).

\subsection{The history of Lake Victoria $\sim 100-35$ ka inferred from terrestrial deposits}


No sediments have yet been recovered from cores beneath the $~ 17-16$ ka unconformity. We infer the earlier history of Lake Victoria from sediments, soils, and fossils from terrestrial deposits that are exposed on Rusinga Island, Mfangano Island and near Karungu, Kenya (Figure 1), using a variety of paleoecological, paleopedological, and biogeochemical analyses to reconstruct ancient habitats and rainfall regimes. It is important to stress that the $\sim 100-35 \mathrm{ka}$ terrestrial data are temporally less continuous than data from the lateglacial lacustrine cores, and span a longer time interval but smaller geographic area. Furthermore, as the sediments from Rusinga, Mfangano, and Karungu are terrestrial rather than lacustrine, they do not provide direct evidence of the extent of the lake during their deposition. As sediment traps, they more likely reflect very local conditions characteristic of topographic lows rather than the region as a whole. This problem is partially offset by our analyses of fossil fauna, which include taxa with larger home ranges that sample larger portions of the landscape (Kingston, 2007). As detailed below, our combined observations from sediments, soils, fossil fauna, and isotopic analyses indicate a reduced or desiccated Lake Victoria with a $\mathrm{C}_{4}$-grass dominated landscape $\sim 100-35$ ka that was more open and drier than today, with locally abundant woody plants concentrated at moisture-rich topographic lows and more rugged slopes on present-day islands.

\subsubsection{The sedimentary record}

The Late Pleistocene sediments from Rusinga Island, Mfangano Island and near Karungu consist largely of alluvial silts and sands, variably developed paleosols, spring-deposited tufas, and primary fall-out and reworked volcanic ashes (tephra) (Tryon et al., 2010; Tryon et al., 2012; Beverly et al., 2015; Faith et al., 2015; Garrett et al., 2015; Beverly et al., in press). The tephras are correlative among the localities (Blegen et al., 2015), indicating that they represent a single, coherent $>10$-m-thick sedimentary record dispersed among outcrops up to $60 \mathrm{~km}$ apart (Figure 2).

The base of the sequence is best exposed at Nyamita on Rusinga Island, with U-series dates of $94.0 \pm 3.3 \mathrm{ka}$ and $111.4 \pm 4.2 \mathrm{ka}$ on tufa providing maximum ages for overlying sediments (Beverly et al., 2015). The locally distinctive and widespread Nyamita Tuff 
defines the middle portion of the stratigraphic sequence (Figure 2). The Nyamita Tuff is associated with optically stimulated luminescence (OSL) dates of $46 \pm 4 \mathrm{ka}$ and $50 \pm 4 \mathrm{ka}$ that bracket a primary fall-out facies, indicating an age of $\sim 49$ ka for its deposition, with an additional three OSL dates producing an average of $68 \pm 5 \mathrm{ka}$ from the Wakondo locality, from strata between the Nyamita Tuff and the dated tufa at the base (Blegen et al., 2015). The age of the upper portions of the sedimentary sequence remain poorly constrained. Three radiocarbon dates on the shells of gastropods that burrowed into the Nyamita Tuff range from $\sim 35-42$ ka (Tryon et al., 2010), providing a reasonable minimum age for the sediments consistent with recovered MSA archaeological assemblages (Tryon and Faith, 2013).

The presence of alluvial sediments and particularly freshwater tufa deposits near the base of the sequence at Nyamita and multiple localities near Karungu (Beverly et al., 2015) suggest that some of the deposits on Rusinga, Mfangano, and near Karungu, sample locally well-watered environments. Active springs at Nyamita and older ( 455 ka) tufas at Karungu indicate that springs are recurrent landscape features. Three widespread paleosols (paleo-vertisols and paleo-inceptisols) occur throughout the stratigraphic sequence (Beverly et al., in press), and estimates of mean annual precipitation (MAP) using weathering indices derived from soil chemical composition (CIA-K and CALMAG) indicate MAP ranges of $813 \pm 182$ to $963 \pm 182 \mathrm{~mm} \mathrm{yr}^{-1}$. These values are $\sim 20-50 \%$ lower than present, and suggest drier conditions throughout much of the $\sim 100$ $35 \mathrm{ka}$ interval.

\subsubsection{Isotopic reconstructions of vegetation}

Following Cerling et al. (2011), the carbon isotopic composition of pedogenic carbonate and associated organic matter from the Nyamita locality at Rusinga (Figure 2) demonstrate that $\mathrm{C}_{3}$ plants were locally abundant in that area during periods of pedogenesis. At Nyamita, woody cover abundance indicates that woodland/bushland/shrub (60-80\%) and grassy woodland/bushland/shrub (40-60\%) ecosystems were dominant with a minor contribution of woody cover associated with wooded grasslands (20-40\%) (Figure 3C) (Garrett et al., 2015). These data reflect a 
single site and may not be representative, but indicate the presence of dense vegetation at some well-watered localities.

\subsubsection{Habitat reconstruction using faunal evidence}

The $\sim 100-35$ ka fossil faunas from Rusinga Island, Mfangano Island, and Karungu are the most taxonomically diverse Late Pleistocene assemblage in East Africa (Tryon and Faith, 2013; Faith, 2014), and are summarized in Table 1. Individuals from extinct taxa account for $>50 \%$ of the large mammals $(>5 \mathrm{~kg}$ ), and include the only reported Late Pleistocene East African occurrences of a suite of extinct taxa, including the bovids Megalotragus sp., Rusingoryx atopocranion, an unnamed impala (Aepyceros sp.), the suid Kolpochoerus sp. and the aardvark Orycteropus crassidens (Lehmann, 2009; Faith, 2014; Faith et al., 2014). At present, much of our fossil sample consists of surface collected specimens. While much of the fauna can be reliably attributed to stratigraphic intervals bounded by characteristic tephra deposits, the total sample is time averaged across $\sim 65 \mathrm{kyr}$.

The fossil fauna from Nyamita and elsewhere include water dependent taxa such as the reedbuck (Redunca spp.), hippopotamus (Hippopotamus sp.), as well as the vlei rat (Otomys sp.), the latter typically found in marshy habitats (Tryon et al., 2010; Tryon et al., 2012; Faith et al., 2015). The presence of these taxa is consistent with the presence of tufas and the vegetation reconstructions from isotopic data. However, as discussed below, several lines of evidence indicate that the $\sim 100-35$ ka fossil faunas from Rusinga Island, Mfangano Island, and Karungu document a $\mathrm{C}_{4}$ grass-dominated ecosystem drier than present that supported diverse populations of grazing herbivores throughout most of the stratigraphic sequence.

\subsubsection{Bovid tribal abundance}

Each of the fossil bovid assemblages is dominated by specimens belonging to the tribes Alcelaphini and Antilopini (Karungu: 76.3\%; Rusinga: 82.5\%; Mfangano: 68.8\%),

particularly the extinct taxa Damaliscus hypsodon and $R$. atopocranion (Table 1). Among modern ecosystems, the abundance of these tribes is indicative of dry grassland 
settings (Vrba, 1980). This impression is reinforced when the fossil assemblages are compared with the community analyses that demonstrate that the bovid abundances by tribe distinguish among wet edaphic grasslands, open/dry habitats, and woodlands (Alemseged, 2003); those from Rusinga Island and Mfangano Island suggest formation in an open/dry habitat similar to the modern Serengeti communities (Tryon et al., 2010; Tryon et al., 2012), and a similar habitat at Karungu can be inferred based on the comparable dominance of Alcelaphini and Antilopini.

\subsubsection{Hypsodonty}

Damaliscus hypsodon - the most hypsodont of known African bovids (Faith et al., 2012) - is one of the most abundant bovids in the Lake Victoria basin. This reflects the widespread presence of a taxon well-suited to feeding on grass in open environments. To the extent that the occlusal relief of maxillary molars among grazing bovids is a reflection of abrasion related to consumption of dry versus wet grasses (see discussions inFortelius and Solounias, 2000; Louys and Faith, 2015), the mesowear signature of D. hypsodon M1s and M2s from the Lake Victoria region, which includes mostly specimens with low occlusal relief (M2 only: $\mathrm{n}=8, \%$ low occlusal relief $=87.5, \%$ round cusps $=100 ; \mathrm{M} 1$, $\mathrm{M} 2$, and M1/2(?): $\mathrm{n}=16, \%$ low occlusal relief $=87.5, \%$ round cusps $=93.8 \%, \%$ blunt cusps $=6.3 \%$ ), suggests a preference for dry grasses.

\subsubsection{Isotopic reconstructions of diet and humidity}

Environmental reconstruction is aided by isotopic analyses of tooth enamel from a large $(n=102)$ and diverse (at least 19 taxa) sample of Late Pleistocene fossils, including large mammalian herbivores (Figure 3A), and rodents (Figure 3B) from the Lake Victoria basin (Faith et al., 2015; Garrett et al., 2015). Based on the isotopic composition of modern $\mathrm{C}_{4}$ (tropical grasses) and $\mathrm{C}_{3}$ (trees, shrubs, herbs) plants, diet-enamel enrichment $\left(\boldsymbol{\varepsilon}^{*}\right)$ of $14.1 \%$, and changes in the isotopic composition of atmospheric $\mathrm{CO}_{2}$, we assign diet categories using a $\delta^{13} \mathrm{C}_{\text {enamel }}$ value of $-8 \%$ as the boundary between $\mathrm{C}_{3}$-browsing (> ca. $75 \% \mathrm{C}_{3}$ ) and $\mathrm{C}_{3} / \mathrm{C}_{4}$ mixed feeding, and $-1 \%$ as the boundary between mixed feeding and $\mathrm{C}_{4}$-grazing (> ca. $75 \% \mathrm{C}_{4}$ ). The isotopic composition of tooth enamel in large mammals from Rusinga, Mfangano, and Karungu demonstrate the dominance of $\mathrm{C}_{4}$ 
grazers (Figure 3A). In some cases (e.g., Taurotragus sp., Potamochoerus sp.), fossil specimens indicate a more $\mathrm{C}_{4}$-dominated diet than modern conspecifics (Garrett et al., 2015). A single analysis of Hippopotamus sp. indicates a more $\mathrm{C}_{3}$-dominated diet than most modern specimens in eastern Africa, which consume a mixed $\mathrm{C}_{3} / \mathrm{C}_{4}$ diet (Cerling et al., 2008; Garrett et al., 2015). This suggests that the ground vegetation layer near aquatic habitats preferred by hippopotamus would have included substantial $\mathrm{C}_{3}$ vegetation, likely including non-woody $\mathrm{C}_{3}$ plants such as herbs. The presence of $\mathrm{C}_{3} / \mathrm{C}_{4}$ mixed feeding individuals in a variety of taxa, including Alcelaphini, Antilopini, Bovini, Reduncini, and Tragelaphini, indicates that $\mathrm{C}_{3}$ browse was available, although most herbivores had a $\mathrm{C}_{4}$ dominated diet, indicating either that $\mathrm{C}_{3}$ plants were not abundant or not preferred (Figure 3A). Following Cerling et al. (2015), the ratio of $\mathrm{C}_{4}$-grazers, mixed $\mathrm{C}_{3} / \mathrm{C}_{4}$ feeders, and $\mathrm{C}_{3}$-browsers (G:M:B) is 67:25:8 (dietary classifications made for bovids at the level of tribe and other taxa at the generic level). This ratio is similar to modern $\mathrm{C}_{4}$ grazer dominated ecosystems, which includes both grassland and mosaic (mixed habitats including grasslands, woodlands, and forests) ecosystems (Cerling et al., 2015).

Oxygen isotopic analyses of these teeth and comparison of the aridity index of Levin et al. (2006) suggest at least a minimum 20\% reduction in mean annual precipitation relative to the present (Garrett et al., 2015). This is consistent with estimates derived from the Karungu paleosols (Beverly et al., in press).

\subsubsection{Biogeography}

Fossils of extant taxa from Rusinga, Mfangano, and Karungu are found well beyond their current range. The most striking examples are the fossils of oryx (Oryx beisa) and Grevy's zebra (Equus grevyi) which indicate a substantial westward home range expansion of $\sim 250-350 \mathrm{~km}$ into the eastern portions of the Lake Victoria basin (Tryon et al., 2010; Faith et al., 2013). Both animals are today restricted to the more arid regions of eastern and northeastern Africa. Fossil data from the Pleistocene and Holocene suggest that the ranges of these and other taxa, particularly the white rhino (Ceratotherium simum), underwent substantial contractions with the onset of more humid conditions during the Holocene (Faith et al., 2013). 


\subsubsection{Population ecology and bathymetry}

Ecological observations suggest that small $\left(\sim 64 \mathrm{~km}^{2}\right)$ islands such as Mfangano that are dominated by steep volcanic uplands are unable to support viable herds of the gregarious and in some cases migratory ungulate species such wildebeest (Connochaetes taurinus), buffalo (Syncerus caffer and S. antiquus), and plains zebra (Equus quagga), at odds with the recovered fossil assemblage (Tryon et al., 2012; Tryon et al., 2014). Modeled changes in lake depth from integrated topographic and bathymetric data suggest that the fossil and archaeological deposits on Mfangano were deposited when the level of Lake Victoria was at least $25 \mathrm{~m}$ lower than present. This reduction in lake depth would have connected the island to the mainland, and provided a sufficiently large landmass to maintain viable populations of the taxa indicated by the fossils (Tryon et al., 2014).

\subsubsection{6 'Non-analog super-communities'}

Within the limits of our temporal resolution, the fossil faunas represent 'non-analog super-communities' with combinations of taxa not found today due to separation by Lake Victoria, including E. grevyi as already noted (found east of Lake Victoria), as well as the white rhino (C. simum), today restricted to areas northwest of the lake, and the southern reedbuck (Redunca arundinum), today found only in Tanzania south of Lake Victoria (Faith et al., 2015; Faith et al., in press). The combination of these animals at multiple sites in the Lake Victoria basin may indicate diffusion into the basin from multiple directions, or their present distribution may represent remnant populations fragmented and isolated by lake expansion. The convergence of mesic-adapted species outside of their current ranges in the late Quaternary sediments deposited during humid conditions in the Kibish Formation of southern Ethiopia (Rowan et al., 2015) provides a complementary perspective, indicating that repeated wet/dry cycles contributed to major reorganization of faunal communities.

\section{A model for human occupation of a dry Lake Victoria basin}

The sedimentary and fossil records indicate that Lake Victoria was desiccated or substantially reduced one or more times during the lateglacial period and from $\sim 100-35$ 
ka. Intervals of lake recession coincided with the expansion of $\mathrm{C}_{4}$ grasses across the basin, and at least during the $\sim 100-35$ ka period, this grassy ecosystem supported a grazer-dominated herbivore community with some taxa representing dry grass specialists and overall faunal similarities to the present-day Serengeti ecosystem. Dated sediments from the V95-2P and Ibis-1 cores indicates that drying, grass expansion and subsequent refilling of the Lake Victoria basin can happen on very brief timescales on the order of $10^{2}-10^{3}$ yr (Talbot and Livingstone, 1989; Talbot and Laerdal, 2000; Stager et al., 2011). Rapid and repeated changes in shoreline position and cycling of habitats from shoreline to grassland serve as powerful push-pull mechanism for the concentration and subsequent dispersal of human populations across the Lake Victoria basin. These are conditions that over the long term can contribute to substantial biological and behavioral variability through processes of isolation, adaptation, drift, and exchange (Vrba, 1985; Faith and Behrensmeyer, 2013), as suggested for the extant and fossil faunal communities in the Lake Victoria basin (Faith et al., 2015; Faith et al., in press). Two factors would have contributed to this pattern of dispersal towards and away from the basin center: the persistent human occupation of lakeshore settings that offered an array of dense, predictable resources throughout the year, and continued hunting of large but mobile and therefore somewhat unpredictable herds of ungulates that populated the grasslands.

\subsection{Human settlement along the shoreline}

The lakeshore likely remained a focal point for human occupation during periods of lake stability, expansion, and contraction because of its proximity to a range of environments and the presence of dense and predictable resources, particularly fish, shellfish, and a variety of different fruits, herbs, and other types vegetation, many of which were available year-round. A lakeshore focus is attested both by contemporary population density around the lake as well as by the Kansyore Holocene shell middens and other sites along Lake Victoria (e.g., Robertshaw et al., 1983; Robertshaw, 1991; Prendergast, 2010; Prendergast and Lane, 2010). Because of this preference, change in lake size and location was likely a primary mechanism for the diffusion of human populations across the Lake Victoria basin throughout the Pleistocene, and occupation likely tracked fluctuations in shoreline location. The shoreline provided accessible fresh water and a 
variety of fish that could be captured in near-shore settings, with or without boats (for detailed discussions of the historic and ethnographic range of fishing techniques used in Equatorial Africa, see Worthington and Worthington, 1933; Stewart, 1989; Peters, 1990, 1991). Shellfish in Lake Victoria known to have been used as food during the Holocene include bivalves Aspatharia, Mutela, and Caelatura (Robertshaw et al., 1983; Prendergast and Lane, 2010) that are most abundant in shallow, relatively calm waters (Muli and Mavuti, 2001; Muli, 2005). Aquatic and semi-aquatic plants such as the water lily (Nymphaea spp.) and sedges (Cypersceae) such as papyrus (Cyperus papyrus) and the bulrush or cattail (Typha spp.) are found in similar water conditions, with water lily and papyrus common on the margins of Lake Victoria today (Lind and Morrison, 1974), with sedges present during the lateglacial as indicated by available pollen data (Kendall, 1969; Beuning, 1999). Water lilies and sedges produce carbohydrate-rich underground storage organs (USOs) that are available throughout the year in dense patches, are easily harvested, and are historically known to have supported large populations of foragers (reviewed in Wrangham et al., 2009). Thus, habitats in close proximity to the lake provided food and other resources found in near-shore tidal flats, swamps, forests, and more open savannas. Foragers based near the lake could also take advantage of seasonal abundances (e.g., flowering vegetation, honey production, game, inland fish spawns) in more distant areas as needed (for discussion, see Ichikawa, 1980; Marean, 1997; Dale et al., 2004; Prendergast, 2010).

Observations from human behavioral ecology and ethnography suggest that settings with a variety of dense, predictable resources, many of them available available throughout the year and not just seasonally, are typified by (1) small defended territories, (2) low residential mobility, (3) informal lithic technologies that are heterogenous at a regional scale due to low degrees of information exchange, (4) the use of multi-season occupations that lead to dense archaeological accumulations and include evidence for the use of aquatic resources (e.g., bone harpoons), and (5) have relatively little evidence for long distance movement or exchange detectable through the presence of non-local lithic raw materials (Ambrose and Lorenz, 1990; Wallace and Shea, 2006). Late Pleistocene Equatorial African archaeological examples that conform to these observations include 
60-70 ka deposits at Katanda and LGM deposits at Ishango, both near Lake Edward (Figure 1) in the Democratic Republic of the Congo, with informal lithic technologies, patchily dense artifact accumulations, and evidence consistent with multi-seasonal occupation (Brooks and Smith, 1987; Peters, 1990; Brooks et al., 1995; Yellen et al., 1995; Yellen, 1996; Helgren, 1997; Feathers and Migliorini, 2001). We predict similar archaeological signatures for Late Pleistocene shoreline sites along Lake Victoria, particularly for shallow, relatively calm bays where shellfish and aquatic and semiaquatic plants with USOs were most abundant, shown as areas with a gentle, uniform offshore slopes in Figure 1.

\subsection{Human settlement in grass-dominated ecosystems}

Grasses likely expanded across the Lake Victoria basin more or less in lockstep with lake retreat. Grasses are among the earliest colonizers in a natural vegetation succession, with existing $\mathrm{C}_{4}$ grasslands near the lake margin facilitating rapid colonization of the lake flats that likely kept pace with lakeshore retreat (cf. Belsky, 1986). Today, $\mathrm{C}_{4}$ grasslands occur in the Serengeti near the southeastern shoreline (Figure 1) as well as along the western shoreline (Lind and Morrison, 1974; Cerling, 1992). Diffusion of populations of herbivorous taxa and associated carnivores would have coincided with the spread of these grasslands towards the center of the basin, as the herbivores tracked their preferred habitats. As human predation on gregarious herbivores is well established in Africa (and elsewhere) by the Late Pleistocene (Marean, 1997; Assefa, 2006; Faith, 2008), we expect that there was the diffusion of groups of human foragers into the basin as well during any Late Pleistocene period of lake reduction, either during the lateglacial or $\sim 100-35 \mathrm{ka}$.

The grassy ecosystems that characterized the Lake Victoria basin during intervals of lake reduction would have offered a different set of resources from those found at the shoreline. Tropical African savanna grasslands are environments where food resources are dense but unpredictable. This is largely due to temporal and spatial uncertainties about the locations of the large herds of mobile ungulates that provide one of the most important potential sources of food (Ambrose and Lorenz, 1990; Marean, 1997). Such settings are typified by large undefended territories, are characterized by high residential 
mobility and the use of highly portable, multi-functional lithic technologies that maximize utility while minimizing weight. In Late Pleistocene Africa these include Levallois approaches to flake production and the use of backed pieces or microliths (e.g., Ambrose and Lorenz, 1990; Wallace and Shea, 2006; Hiscock et al., 2011; Eren and Lycett, 2012). Lithic assemblages are relatively homogenous over large areas due to high levels of mobility and information exchange between groups, occupations are sparse and typically short, and show strong evidence for long distance movement through non-local lithic raw materials (Ambrose and Lorenz, 1990).

Although overall resource predictability is low, certain places on the landscape may see recurrent use because of the presence of predictable resources, and these areas likely accumulated a more dense archaeological record. Examples include sources of fresh water (both for drinking and the expected presence of game) and outcrops of stone suitable for tool manufacture. Topography also plays an important factor in determining which areas likely saw recurrent use. Topographic lows are sediment and moisture traps, topographically rough areas are typically avoided by grazing ungulates, and both areas are characterized by high vegetation diversity with non-grass species preferentially targeted by human foragers (see Ichikawa, 1980; Tryon et al., 2014). Plants with underground storage organs are typically abundant on well-drained, nutrient-poor soils formed on slopes (Vincent, 1985; Marean, 1997). In the case of Lake Victoria, many of the present day islands would have been transformed into inselbergs or hills that overlooked relatively smooth grassy areas during periods of lake recession. These topographic high points would also have provided excellent vantage points to observe migratory game as well as other human populations on the surrounding plains (see also Jochim, 1976; Clark, 2001) and would have been highly visible, prominent features on the landscape, serving as visual anchors for navigation, as territorial markers or places of aggregation, and perhaps as sacred places (Bernardini et al., 2013). The attractiveness of these locales would be increased if fresh water and lithic raw material sources were also nearby. MSA archaeological sites with Levallois technology on inselbergs that were likely occupied to take advantage of seasonal game migrations include Nasera rockshelter in Tanzania (Mehlman, 1977; Mehlman, 1989) and GvJm-22 at Lukenya Hill in Kenya 
(Marean, 1997; Tryon et al., 2015), sites overlooking the dry grasslands of the Serengeti and Athi-Kapiti plains, respectively.

\section{Lake Victoria's lateglacial and $\sim \mathbf{1 0 0 - 3 5}$ ka archaeological record}

We explore these models for human diffusion across the Lake Victoria basin during periods of lake level decline using archaeological data from the lateglacial and 100-35 ka intervals. The nature of our data dictates complementary approaches. Our lateglacial dataset is focused on diachronic change from a rich artifact record from a single LSA site from an island, useful for assessing the timing of the occupation of the basin relative to lake level fluctuations. In contrast, the evidence from $\sim 100-35 \mathrm{ka}$ consists of a sparse record from multiple MSA sites within a broad temporal envelope. For the older period, we shift our focus from questions of temporal variation to geographic variation, emphasizing the extent to which the MSA archaeological record of the Lake Victoria basin defines regional similarities and discontinuities that provide evidence for diffusion from neighboring areas.

\subsection{The lateglacial archaeological record}

The post-LGM and terminal Pleistocene archaeological record of the Lake Victoria basin (Figure 1) is restricted to lithic data from Munyama Cave, Uganda (fossil flora and fauna are not preserved) and perhaps basal strata at Siror, Kenya (Dale and Ashley, 2010) although details from the Pleistocene strata at Siror are lacking. In contrast, the record from Munyama Cave is dense but obscure, restricted to two very brief published syntheses in English (Nenquin, 1971; Van Noten, 1971), as well as a brief synthesis (Van Noten, 1970) and an unpublished but data-rich thesis in Dutch (Valcke, 1974). The Munyama Cave record is well suited to explore the relationship between changes in human occupation of the Lake Victoria region with the drying of the lake and subsequent refilling of the basin, as it is $<15 \mathrm{~km}$ from the P-2 core recovered from Pilkington Bay on the northern shore of Buvuma Island (Figure 1), a well-dated core $\left(n=28{ }^{14} \mathrm{C}\right.$ dates over $17.66 \mathrm{~m}$ thickness) that contains a detailed palynological record spanning the last $\sim 18 \mathrm{kyr}$ (Kendall, 1969), permitting a detailed comparison of the archaeological record with a proximal paleoenvironmental archive. 
Munyama Cave is a modest sized cave $\left(220 \mathrm{~m}^{2}\right) \sim 28.5 \mathrm{~m}$ above current lake level overlooking Gaya Bay on the southwestern side of Buvuma Island. The island is today opposite Lake Victoria's main outlet at Jinja and is separated from mainland Uganda by a $<1 \mathrm{~km}$ wide and < $9 \mathrm{~m}$ deep channel (MacIntyre et al., 2002). During lake level retreat, the site would have overlooked a major buried river channel to the west of the island (Figure 1). Excavation of $18 \mathrm{~m}^{2}$ in 1968 yielded a stratified (1.4-m-thick), rich ( $n>$ 166,000) quartz-dominated (>98\%) LSA archaeological sequence (Figure 4) with backed pieces (microliths) comprising an average of $\sim 53 \%$ of the retouched tools (Valcke, 1974). Outcrops of quartz suitable for tool production occur locally on the island (Wayland, 1925). Four stratigraphically coherent radiocarbon dates from $50-90 \mathrm{~cm}$ below the surface range from $11,187 \pm 292{ }^{14} \mathrm{C}$ yr BP to $18,218 \pm 245{ }^{14} \mathrm{C}$ yr BP (Nenquin, 1971) when calibrated using OxCal 4.2 software and the IntCal13 calibration curve (Reimer et al., 2013). The assemblage shows no consistent changes in artifact typology over time, but does record substantial shifts in artifact density throughout the stratigraphic sequence (Valcke, 1974) that suggest changes in occupation intensity throughout the cave's history.

Figure 5 plots artifact density by depth for Munyama Cave and the position of the radiocarbon dates, with an age-depth model of pollen spectra from the P-2 core plotted for comparison. The archaeological data show that peak occupation (as measured by artifact density) is broadly coincident with the timing of the $\sim 17-16$ ka desiccation event for Lake Victoria and the spread of $\mathrm{C}_{4}$ grasses. The four radiocarbon-dated samples show a linear increase in age with depth $\left(\mathrm{r}^{2}=0.958, p=0.042\right)$, using the midpoint of the 10-cm-thick stratum for each reported dated sample. This relationship allows us to interpolate an age-depth relationship for the $50-90 \mathrm{~cm}$ below surface (cmbs) levels. Extrapolation much beyond 50-90 cmbs makes unwarranted assumptions about regular sedimentation rates, but using the regression to calculate ages for adjacent bounding strata (40-50 cmbs and 90-100 cmbs) provides at least reasonable age estimates that allow us to better understand the pattern of human occupation at the site. The results suggest that there is a marked increase in occupation intensity in the $90-100 \mathrm{~cm}$ level 
(extrapolated age $=21.4 \mathrm{ka}$ ) during the LGM. Although we lack direct evidence for the conditions of Lake Victoria during the LGM, pollen data from the Rwanda and Burundi highlands (Bonnefille and Chalie, 2000) suggest increased aridity near the headwaters of the western part of the basin that would have contributed to a reduction in the area and volume of Lake Victoria, consistent with reductions in other tropical African lakes at this time (Gasse et al., 2008). Given the narrow and shallow channel separating Buvuma Island from the mainland, it may well have been connected to the mainland during the LGM. There is a rapid drop in artifact abundances in the 60-70 cmbs stratum; the interpolated depth for the connection of Lake Victoria to the Nile at $\sim 13 \mathrm{ka}$ (Beuning et al., 2002) is $\sim 62 \mathrm{cmbs}$, suggesting a connection between reduced occupation intensity and high lake levels. Finally, artifact abundances fall substantially after the $40-50 \mathrm{cmbs}$ level, with an extrapolated age of $8.6 \mathrm{ka}$, a date by which the pollen records from the proximal P-2 core and more distant V95-2P cor (Kendall, 1969; Beuning, 1999) indicates that grass (Poaceae) pollen abundance is at a minimum and tree pollen (primarily Moraceae) is at its maximum abundance (Figure 5).

In sum, the record from Munyama Cave suggests that occupation intensity is inversely related to lake level, indicating that human use of portions of the basin may have tracked lake contraction and expansion. That peak occupation density coincides with lake desiccation $\sim 17-16$ ka suggests that the site's utility to foragers may have been greater as a topographic high point overlooking a $\mathrm{C}_{4}$ grass-dominated ecosystem rather than as an island, perhaps because offshore conditions were not conducive to dense shellfish or aquatic/semi-aquatic USO plant populations. The retouched tool component is dominated by backed microliths throughout the Pleistocene, consistent with use by groups living in areas characterized by dense but unpredictable resources (e.g., migratory game), although actual distance to the shoreline is unknown for most of the site's history. The lack of faunal or floral remains makes it difficult to infer if the site represents a residential area or a shelter repeatedly occupied on a seasonal basis, and the artifacts are made almost exclusively of quartz (no obsidian is reported), and thus assessing connections with more distant areas is not possible. 


\subsection{Archaeological evidence from $\sim 105-35 \mathrm{ka}$}

All MSA sites from the Lake Victoria basin occur in terrestrial sediments with no clear evidence for proximity to a lake, as Holocene refilling of the basin eroded or buried shorelines formed during periods when the lake was smaller than present. Holocene archaeological sites are associated with the $+3 \mathrm{~m}$ strandline around the lake (Brachi, 1960; Lane et al., 2006), but whether the $+10-12 \mathrm{~m}$ or $+18 \mathrm{~m}$ deposits date to the Holocene or Pleistocene is unknown, and as yet, no archaeological sites are known from either of them. The recovery of archaeological sites contemporary with the $+10-12 \mathrm{~m}$ or $+18 \mathrm{~m}$ strandlines remains a focus of ongoing research.

Of the MSA sites in the basin, the best described are those from Rusinga Island, Mfangano Island, and Karungu, and these consist of lithic artifacts (and rare cut-marked and percussed bones) collected during pedestrian survey, systematic surface collection, and excavation (Tryon et al., 2010; Jenkins et al., 2012; Tryon et al., 2012; Faith et al., 2015). Of these, Rusinga Island in particular offered a combination of topographic highpoints, fresh water springs, and locally available sources of high quality lava and chert raw materials (Tryon et al., 2014). The combined assemblage from Rusinga Island, Mfangano Island, and Karungu $(n>750)$, portions of which is derived from surfacecollected material targeting only technologically diagnostic specimens, consists of flakes and blades removed from a variety of Levallois, discoidal, and single- and multi-platform cores (Figure 4). Retouched pieces are rare, but include side scrapers and small $(<5 \mathrm{~cm})$ unifacial and bifacial points (Figure 4). Artifacts are made primarily of a diverse array of locally available lavas, chert, quartz, and quartzite, as well as rare obsidian artifacts from sources in the Central Rift of Kenya, $250 \mathrm{~km}$ to the east (Faith et al., 2015). Points and Levallois flakes are often made on unique raw material types, suggesting they entered the archaeological record far from the place of manufacture (Tryon et al., 2010), consistent with expected use by highly mobile groups as predicted for grassland settings with dense but unpredictable resources. Artifact density is low (Garrett et al., 2015), and the combined evidence is consistent with the interpretation that we are primarily sampling areas of hominin tool use and discard rather than areas of tool production or prolonged occupation (cf. Roebroeks, 1988; Conard and Adler, 1997), many likely 
related to prey acquisition. Notably, the fossil assemblages are dominated by gregarious and probably migratory bovids $D$. hypsodon and $R$. atopocranion (Table 1; Faith et al., 2012), some of which were clearly hunted using mass-capture techniques (Jenkins et al., 2012).

Other MSA sites with small points and evidence for Levallois technology occur around the margin of Lake Victoria (Figure 1 and Figure 4). These include collections from present-day islands that would have been connected to the mainland with the $25 \mathrm{~m}$ lake level drop suggested by evidence from Mfangano Island (Tryon et al., 2014), including Lolui and Bugaia Islands in Uganda (Nenquin, 1971; Posnansky et al., 2005). Other near-shore sites include Chole rockshelter, Ruhanga rockshelter, Kibwera and Loiyangalani in Tanzania (Soper and Golden, 1969; Bower and Grogan-Porter, 1981; Bower et al., 1985; Reid and Njau, 1994; Kwekason and Chami, 2003), and Muguruk, Songhor, and perhaps Randhore rockshelter in Kenya (Gabel, 1969; McBrearty, 1981, 1988). Walasi Hill in Uganda (O'Brien, 1939) lies just outside the basin margin at the foot of Mt. Elgon and near the headwaters of Lake Kyoga (Figure 1), a region speculated to be an important source of water for the region during Lake Victoria's reduction (Livingstone, 1976: 24; Van Damme and Van Bocxlaer, 2009: 586). Unfortunately, none of these sites are well dated, and the artifact assemblages are in general only summarily described. Despite the coarseness of the available archaeological data, three general patterns emerge relevant to human occupation of the Lake Victoria basin.

\subsubsection{A different archaeological record from sites west of Lake Victoria}

Small point and Levallois based assemblages from the Lake Victoria basin are quite distinct from Late Pleistocene deposits in central Africa, further to the west. These are best represented at the $\sim 60-70 \mathrm{ka}$ Katanda sites, where an informal quartz-based industry occurs with shaped uni- and biserial bone harpoons (Brooks et al., 1995; Yellen et al., 1995; Yellen, 1998; Feathers and Migliorini, 2001), but also include the undated site of Rutonde, Rwanda (Nenquin, 1967). The absence of Levallois technology and bifacial points at these sites is not explained by raw material properties, as quartz Levallois cores and bifacial points are found at Rusinga Island and Karungu in the Lake Victoria basin 
and Walasi Hill at the foot of Mt. Elgon (Figure 4). Older (likely Middle Pleistocene) sites such as Masango in Burundi (Van Noten et al., 1972) further indicate the use of Levallois technology and the production of bifaces in regions west of Lake Victoria. These differences may be better explained by differences in resource predictability. Although environmental details are lacking for Rutonde, sites at Katanda suggest use of a range of terrestrial and seasonally available aquatic resources (Brooks et al., 1995; Helgren, 1997).

\subsubsection{Archaeological similarities to areas east of Lake Victoria}

Late Pleistocene small point and Levallois-based assemblages similar to those found around Lake Victoria are common throughout the eastern portion of the EARS and surrounding areas, which may indicate the westward expansion of technological traditions (and possibly populations) into the Lake Victoria basin (Tryon et al., 2012; Tryon and Faith, 2013; Faith et al., in press). The presence of eastern Rift Valley obsidian at MSA sites along Lake Victoria further demonstrates the connections between these areas during the Late Pleistocene (Faith et al., 2015).

Contemporaneous MSA archaeological sites with faunal assemblages similar to those from Rusinga Island, Mfangano Island, and Karungu include Nasera rockshelter in Tanzania (Mehlman, 1977; Mehlman, 1989) and GvJm-22 at Lukenya Hill in Kenya (Marean, 1997; Tryon et al., 2015), sites overlooking major migration pathways on the dry grasslands of the Serengeti and Athi-Kapiti plains, respectively (Figure 1). For sites on the eastern margin of Lake Victoria, the Serengeti and other dry grass plains east of the lake may have been a source area for the diffusion of plant, animal, and human populations.

\subsubsection{Similarities to areas north of Lake Victoria}

Faith et al. (2015) conducted a more formal analysis based on the geographic distribution of 14 different artifact types among a sample of 30 Late Pleistocene archaeological assemblages from across eastern Africa. The analysis indicates distinct differences in the

artifact compositions of sites on either side of the Equator. Northern sites $\left(>5^{\circ} \mathrm{N}\right)$ are 
distinguished from those at or below the Equator by less frequent use of bipolar cores and anvils, and more frequent use of Levallois points and cores and large bifaces (Faith et al., 2015). Significantly, exceptions to this geographic pattern include the samples from Rusinga Island and Karungu, Equatorial sites that show a 'northern' technological pattern unlike other southern sites. When combined with data indicating archaeological similarities to areas east of Lake Victoria, this observation suggests occupation of the basin from multiple directions about the periphery of the lake, parallel to observations about the formation of faunal non-analog super communities (Faith et al., 2015).

\section{Conclusions}

Seismic surveys and lake sediment cores demonstrate that Lake Victoria was desiccated or significantly reduced in size multiple times throughout the Pleistocene, most prominently at $\sim 17-16 \mathrm{ka}$. One or more additional such events are inferred from discontinuous near-shore terrestrial deposits dating to $100-35 \mathrm{ka}$. Periodic drying of the largest lake in Africa would have had a profound impact on the composition of local floral and faunal communities. Multiple lines of geochemical, ecological, and fossil evidence from both sediment cores and near-shore terrestrial deposits suggest that the spread of a $\mathrm{C}_{4}$ grass-dominated ecosystem accompanied lakeshore retreat, at least in the eastern, northern, and central portions of the basin where data are available. The replacement of the lake with a grassland would have removed major dispersal barriers to a host of terrestrial animals, contributed to the range expansion of a number of dry grassland-adapted grazing herbivores, and led to the formation of non-analog supercommunities (Tryon et al., 2010; Faith et al., 2013; Faith et al., in press).

Humans were apparently part of this process of range expansion and population diffusion, with groups likely tracking the movement of both the resource-rich shoreline and herbivores. The Later Stone Age evidence from Munyama Cave on Buvuma Island shows a clear and strong correspondence between lake level decline and increased occupation intensity, particularly during the $\sim 17-16 \mathrm{ka}$ desiccation event, indicating increased use of portions of the basin as lake level fell. Reliance on near-shore resources during the Late Pleistocene remains speculative, as much of the relevant evidence has 
been eroded or buried with subsequent lake level rise during the Holocene, but has the potential to be tested by targeted survey for raised shoreline deposits. A suite of technological and typological factors suggest strong similarities among the $\sim 100-35 \mathrm{ka}$ Middle Stone Age archaeological assemblages from Rusinga Island, Mfangano Island, and near Karungu with areas to the east and north of Lake Victoria. Although speculative, areas to the east and north may well have been the source regions for the $\mathrm{C}_{4}$ grassland ecosystems that expanded into the basin; similarities between the fossil fauna and Serengeti ecosystem to the east are particularly strong.

Repeated Pleistocene contraction and expansion of Lake Victoria and $\mathrm{C}_{4}$ grass ecosystems provides an explanation for much of the legacy of environmental heterogeneity that characterizes the Lake Victoria basin today (Cowling et al., 2008; Linder et al., 2012; Lorenzen et al., 2012; Faith et al., 2015; Faith et al., in press). As a push-pull mechanism that repeatedly drew human populations towards the basin center with drying and caused their dispersal with lake expansion, the environmental flux of Lake Victoria may have led to the repeated isolation and combination of diverse populations of foragers that ultimately could have contributed to the diversity of Pleistocene human foragers across Equatorial Africa (e.g., Lahr and Foley, 1998; Harvati et al., 2011; Pearson, 2013; Tryon et al., 2015).

The environmental history of Lake Victoria has to be understood in a broader context. One distinctive feature of the Lake Victoria record is that the occupation of new landscapes, particularly those in the center of the basin, occurred during periods of increased aridity, as reduced moisture availability led to a reduction in lake volume and particularly surface area, and human populations tracked both the shrinking shoreline and herbivores moving into the area. In other areas in Africa such as the Sahara as well as the Arabian Peninsula, it was during intervals of reduced aridity that humans colonized new landscapes, particularly as deserts were transformed into grasslands (Drake et al., 2011; e.g., Rose et al., 2011; Groucutt and Petraglia, 2012; Scerri et al., 2014; but see Will et al., 2015). Latitudinal gradients in environmental change across Africa during the Pleistocene result in regions such as Equatorial Africa and the Sahara being out of phase, 
with drier periods near the Equator at times coinciding with more humid intervals in the Sahara (Blome et al., 2012). By removing potential dispersal barriers (e.g., large lakes and deserts), these differing environmental regimes may have both offered conditions conducive to human expansions beyond Equatorial Africa, and their coincidence 105-80 ka has been linked to dispersals across and out of Africa (Cohen et al., 2007; Scholz et al., 2007; Blome et al., 2012). The Nile River has long been considered a corridor for migration and a connector to sub-Saharan Africa, particularly for the spread of Lupemban and Nubian MSA industrial complexes (for a recent review, see Scerri, 2013), but MSA sites on the White or main Nile are restricted to north of Khartoum at $\sim 15^{\circ} \mathrm{N}$ (see Masojć, 2010; Rose et al., 2011), with the exception of a few surface-collected Levallois cores near Juba in South Sudan at $\sim 4^{\circ} 50^{\prime} \mathrm{N}$ (Philipson, 1981). Given Lake Victoria’s present position of the headwaters of the Nile, additional inter-regional comparisons between the Lake Victoria basin and regions to the north are certainly warrented.

\section{Acknowledgements}

We would like to thank Brian Chase for the invitation to participate in the inaugural AFQUA conference, Els Cornelissen for facilitating access to Valcke's thesis stored at the Royal African Museum at Tervuren, and Stephanie Cousin for its translation into English. Sheila Nightingale provided the excellent artifact illustrations, and Erik OtarolaCastillo provided some important insights on the spread of grasslands. The manuscript also benefitted substantially from the efforts of two anonymous reviewers. Fieldwork reported here was conducted under research permits NCST/5/002/R/576 issued to CAT, NCST/RCD/12B/012/31 issued to JTF, NCST/RCD/12B/01/07 issued to DJP, and NCST/5/002/R/605 issued to EJB, and an exploration and excavation license issued by the National Museums of Kenya (NMK). Research was made possible through the support of the NMK and funding from the National Geographic Society Committee for Research and Exploration (9284-13 and 8762-10), the National Science Foundation (BCS-1013199 and BCS 1013108), the Leakey Foundation, the Geological Society of America, the Society for Sedimentary Geology, the University of Queensland, Baylor University, the Baylor University Department of Geology Dixon Fund, New York University, the American School for Prehistoric Research, and Harvard University. 


\section{Figures and tables}

Figure 1. Sketch map of Equatorial Africa and the Lake Victoria basin (after Temple, 1966; Sinclair, 1979; Stager et al., 1986; Johnson et al., 2000). Lake cores: (1) Ibis-1, (2) P-2, (3) Ibis-3, (4) V95-1P, (5) V95-6P, (6) V95-2P, (7) V96-7P, (8) V95-3P. Note that V96-7P is at the deepest point in the lake. Archaeological sites: (1) Kibwera, (2) Ruhanga rockshelter, (3) Chole rockshelter, (4) Munyama Cave (5) Lolui Island, (6) Walasi Hill, (7) Mfangano Island, (8) Rusinga Island, (9) Karungu, (10) Randhore, (11) Muguruk, (12) Songhor, (13) Lukenya Hill, (14) Nasera, (15) Rutonde, (16) Katanda, (17) Ishango, (18) Masango, (19) Siror, (20) Loiyangalani.

Figure 2. Composite stratigraphic sections for Pleistocene deposits on Rusinga Island, Mfangano Island, and at Karungu, Kenya, including available radiometric dates and tephra correlations (dashed lines). Note that the Bivariate Trachyphonolitic Tuff is not definitively at Walangani, although it is found elsewhere on Mfangano Island. Stars denote archaeological excavations.

Figure 3. Carbon isotopic composition of tooth enamel from (A) fossil large mammalian herbivores from Rusinga, Mgangano, and Karungu, (B) rodents from Karungu, and (C) paleosol carbonates and organic matter from Rusinga. $\delta^{13} \mathrm{C}_{\text {enamel }}$ value of $-8 \%$ as the boundary between $\mathrm{C}_{3}$-browsing (>ca. $75 \% \mathrm{C}_{3}$ ) and $\mathrm{C}_{3} / \mathrm{C}_{4}$ mixed feeding, and $-1 \%$ as the boundary between mixed feeding and $\mathrm{C}_{4}$-grazing (>ca. $75 \% \mathrm{C}_{4}$ ), assuming diet-enamel enrichment $\left(\boldsymbol{\varepsilon}^{*}\right)$ of $14.1 \%$. For rodents we do not assign specific diet categories, although we identify the boundary between $\mathrm{C}_{3} / \mathrm{C}_{4}$ mixed feeding and $\mathrm{C}_{4}$-grazing using a dietenamel enrichment $\left(\boldsymbol{\varepsilon}^{*}\right)$ of $11 \%$.

Figure 4. Artifacts from the Lake Victoria basin and vicinity: (a) quartz bipolar core, Munyama Cave, (b) quartz backed microlith, Munyama Cave, (c) quartz bifacial point, Karungu, (d) quartz bifacial point, Walasi Hill, (e-f) quartz bifacial points from Chole rockshelter, (g) chert flake from a centripetally flaked core, Randhore (h) quartz Levallois core on flake, Walasi Hill, (i) chert Levallois core on flake, Randhore rockshelter, (i) lava 
Levallois core, Karungu. Artifacts from Munyama, Karungu, and Chole are redrawn from Soper and Golden (1969); Van Noten (1971); Faith et al. (2015). Those from Walasi Hill and Randhore are drawn from artifacts stored at the National Museums of Kenya and Boston University's Creighton Gabel Museum, respectively.

Figure 5. Artifact density and calibrated radiocarbon dates plotted by depth for Munyama Cave, Buvuma Island, Uganda, with data from Valcke (1974). Shown in grey are major events in the history of Lake Victoria, plotted against the pollen record of the P-2 core from Pilkington Bay, Buvuma Island, after Kendall (1969) and Berke et al. (2012).

Table 1. Fossil fauna and abundances from Rusinga Island, Mfangano Island, and near Karungu, Kenya, dated to $\sim 100-35$ ka.

\section{References}

Ahmad, N., 1996. Occurrence and distribution of Vertisols, in: Ahmad, N., Mermut, A. (Eds.), Vertisols and Technologies for Their Management. Elsevier Science B.V., Amsterdam, pp. 1-42.

Alemseged, Z., 2003. An integrated approach to taphonomy and faunal change in the Shungura Formation (Ethiopia) and its implications for hominid evolution. Journal of Human Evolution 44, 451-478.

Ambrose, S.H., Lorenz, K.G., 1990. Social and ecological models for the Middle Stone Age in southern Africa, in: Mellars, P. (Ed.), The Emergence of Modern Humans: An Archaeological Perspective. Edinburgh University Press, Edinburgh, pp. 3-33.

Assefa, Z., 2006. Faunal remains from Porc-Epic: Paleoecological and zooarchaeological investigations from a Middle Stone Age site in southeastern Ethiopia. Journal of Human Evolution 51, 50-75.

Belsky, A.J., 1986. Revegetation of artificial disturbances in grasslands of the Serengeti National Park, Tanzania. II: Five years of successional change. Journal of Ecology 74, 937-951. 
Berke, M.A., Johnson, T.C., Werne, J.P., Grice, K., Schouten, S., Sinninghe Damsté, J.S., 2012. Molecular records of climate variability and vegetation response since the Late Pleistocene in the Lake Victoria basin, East Africa. Quaternary Science Reviews 55, 5974.

Bernardini, W., Barnash, A., Kumler, M., Wong, M., 2013. Quantifying visual prominence in social landscapes. Journal of Archaeological Science 40, 3946-3954.

Beuning, K.R.M., 1999. A re-evaluation of the Late Glacial and early-Holocene vegetation history of the Lake Victoria region, East Africa. Palaeoecology of Africa and the Surrounding Islands 26, 115-136.

Beuning, K.R.M., Kelts, K., Russell, J., Wolfe, B.B., 2002. Reassessment of Lake Victoria-Upper Nile River paleohydrology from oxygen isotope records of lake-sediment cellulose. Geology 30, 559-562.

Beverly, E.J., Driese, S.G., Peppe, D.J., Arellano, L.N., Blegen, N., Faith, J.T., Tryon, C.A., in press. Reconstruction of a semi-arid late Pleistocene paleocatena from the Lake Victoria region, Kenya. Quaternary Research.

Beverly, E.J., Driese, S.G., Peppe, D.J., Johnson, C.R., Michel, L.A., Faith, J.T., Tryon, C.A., Sharp, W.D., 2015. Recurrent spring-fed rivers in a Middle to Late Pleistocene semi-arid grassland: implications for environments of early humans in the Lake Victoria basin of Kenya. Sedimentology 62, 1611-1635.

Bishop, W.W., 1969. Pleistocene Stratigraphy in Uganda. Geological Survey of Uganda, Entebbe.

Blegen, N., Tryon, C.A., Faith, J.T., Peppe, D.J., Beverly, E.J., Li, B., Jacobs, Z., 2015. Distal tephras of the eastern Lake Victoria basin, Equatorial East Africa: correlations, chronology, and a context for early modern humans. Quaternary Science Reivews 122, 89-111.

Blome, M.W., Cohen, A.S., Tryon, C.A., Brooks, A.S., Russel, J., 2012. The environmental context for the origins of modern human diversity: A synthesis of regional variability in African climate 150,000-30,000 years ago. Journal of Human Evolution 62, 563-592.

Bonnefille, R., Chalie, F., 2000. Pollen-inferred precipitation time-series from equatorial mountains, Africa, the last $40 \mathrm{kyr}$ BP. Global and Planetary Change 26, 25-50. 
Bootsma, H.A., Hecky, R.E., 2003. A comparative introduction to the biology and limnology of the African Great Lakes. Journal of Great Lakes Research 29 (Supplement 2), 3-18.

Bower, J.R.F., Gifford, D.P., Livingstone, D., 1985. Excavations at the Loiyangalani Site, Serengeti National Park, Tanzania. National Geographic Society Research Reports (1979 Projects) 20, 41-56.

Bower, J.R.F., Grogan-Porter, P., 1981. Prehistoric Cultures of the Serengeti National Park, Tanzania. Papers in Anthropology No. 3, Department of Sociology and Anthropology, Iowa State University, Ames.

Brachi, R.M., 1960. Excavation of a rock shelter at Hippo Bay, Entebbe. Uganda Journal 24, 62-70.

Broecker, W.S., Peteet, D., Hajdas, I., Lin, J., Clark, E., 1998. Antiphasing between rainfall in Africa's Rift Valley and North America's Great Basin. Quaternary Research $50,12-20$.

Brooks, A.S., Helgren, D.M., Cramer, J.M., Franklin, A., Hornyak, W., Keating, J.M., Klein, R.G., Rink, W.J., Schwarcz, H.P., Smith, J.N.L., Stewart, K., Todd, N.E., Verniers, J., Yellen, J.E., 1995. Dating and context of three Middle Stone Age sites with bone points in the upper Semliki Valley, Zaire. Science 268, 548-553.

Brooks, A.S., Smith, C.C., 1987. Ishango revisited: new age determinations and cultural interpretations. African Archaeological Review 5, 65-78.

Brown, F.H., McDougall, I., Fleagle, J.G., 2012. Correlation of the KHS Tuff of the Kibish Formation to volcanic ash layers at other sites, and the age of early Homo sapiens (Omo I and Omo II). Journal of Human Evolution 63, 577-585.

Campbell, M.C., Hirbo, J.B., Townsend, J.P., Tishkoff, S.A., 2014. The peopling of the African continent and the diaspora into the new world. Current Opinion in Genetics and Development 29, 120-132.

Cerling, T.E., 1992. Development of grasslands and savannas in East Africa during the Neogene. Palaeogeography Palaeoclimatology Palaeoecology 97, 241-247.

Cerling, T.E., Andanje, S.A., Blumenthal, S.A., Brown, F.H., Chritz, K.L., Harris, J.M., Hart, J.A., Kirera, F.M., Kaleme, P., Leakey, L.N., Leakey, M.G., Levin, N.E., Manthi, F.K., Passey, B.H., Uno, K.T., 2015. Dietary changes of large herbivores in the Turkana 
Basin, Kenya from 4 to 1 Ma. Proceedings of the National Academy of Sciences 112, 11467-11472.

Cerling, T.E., Harris, J.M., Cramer, J.M., Kaleme, P., Leakey, M.G., Levin, N.E., Lewison, R.L., Passey, B.H., 2008. Stable isotope ecology of the common hippopotamus. Journal of Zoology 276, 204-212.

Cerling, T.E., Wynn, J.G., Andanje, S., Bird, M.I., Korir, D.K., Levin, N.E., Mace, W., Macharia, A.N., Quade, J., Remien, C.H., 2011. Woody cover and hominin environments in the past 6 million years. Nature 476, 51-56.

Chorowicz, J., 2005. The East African rift system. Journal of African Earth Sciences 43, $379-410$.

Chritz, K.L., Marshall, F.B., Zagal, M.E., Kirera, F., Cerling, T.E., 2015. Environments and trypanosomiasis risks for early herders in the later Holocene of the Lake Victoria basin, Kenya. Proceedings of the National Academy of Sciences 112, 3674-3679.

Clark, J.D., 2001. Ecological and behavioral implications of the siting of Middle Stone Age rockshelter and cave settlements in Africa, in: Conard, N.J. (Ed.), Settlement Dynamics of the Middle Paleolithic and Middle Stone Age. Kerns Verlag, Tübingen, pp. 91-98.

Clark, P.U., Dyke, A.S., Shakun, J.D., Carlson, A.E., Clark, J., Wohlfarth, B., Mitrovica, J.X., Hostetler, S.W., McCabe, A.M., 2009. The Last Glacial Maximum. Science 325, 710-714.

Cohen, A.S., Stone, J.R., Beuning, K.R.M., Park, L.E., Reinthal, P.N., Dettmar, D., Scholz, C.A., Johnsor, T.C., King, J.W., Talbot, M.R., Brown, E.T., Ivory, S.J., 2007. Ecological consequences of early Late Pleistocene megadroughts in tropical Africa. Proceedings of the National Academy of Sciences 104, 16422-16427.

Conard, N.J., Adler, D.S., 1997. Lithic reduction and hominid behavior in the Middle Paleolithic of the Rhineland. Journal of Anthropological Research 53, 147-175.

Cowling, S.A., Cox, P.M., Jones, C.D., Maslin, M.A., Peros, M., S.A., S., 2008. Simulated glacial and interglacial vegetation across Africa: Implications for species phylogenies and trans-African migration of plants and animals. Global Change Biology $14,827-840$. 
Crevecoeur, I., Rougier, H., Grine, F., Froment, A., 2009. Modern human cranial diversity in the Late Pleistocene of Africa and Eurasia: Evidence from Nazlet Khater, Peştera cu Oase, and Hofmeyr. American Journal of Physical Anthropology 140, 347358.

Crul, R.C.M., 1995. Limnology and Hydrology of Lake Victoria. . UNESCO, Studies and Reports in Hydrology 53, Dijon.

Dale, D., Ashley, C.Z., 2010. Holocene hunter-fisher-gatherer communities: New perspectives on Kansyore using communities of Western Kenya. Azania: Archaeological Research in Africa 45, 24-48.

Dale, D., Marshall, F., Pilgrim, T., 2004. Delayed-return hunter-gatherers in Africa? Historic perspectives from the Okiek and archaeological perspectives from the Kansyore, in: Crothers, G.M. (Ed.), Hunters and Gatherers in Theory and Archaeology. Center for Archaeological Investigations Occasional Paper No. 31, Southern Illinois University, Carbondale, pp. 340-375.

Danley, P.D., Husemann, M., Ding, B., DiPietro, L.M., Beverly, E.J., Peppe, D.J., 2012. The impact of the geologic history and paleoclimate on the diversification of East African cichlids. International Journal of Evolutionary Biology 2012, 574851.

Doornkamp, J.C., Temple, P.H., 1966. Drainage and tectonic instability in part of southern Uganda. The Geographic Journal 132, 238-252.

Drake, N.A., Blench, R.M., Aritage, S.J., Bristow, C.S., White, K.H., 2011. Ancient watercourses and biogeography of the Sahara explain the peopling of the desert. Proceedings of the National Academy of Sciences of the USA 108, 458-462.

Eren, M.I., Lycett, S.J., 2012. Why Levallois? A morphometric comparison of experimental "preferential" Levallois flakes versus debitage flakes. PLoS One 7, e29273.

Faith, J.T., 2008. Eland, buffalo, and wild pigs: were Middle Stone Age humans ineffective hunters? Journal of Human Evolution 55, 24-36.

Faith, J.T., 2014. Late Pleistocene and Holocene mammal extinctions on continental Africa. Earth-Science Reviews 128, 105-121.

Faith, J.T., Behrensmeyer, A.K., 2013. Climate change and faunal turnover: testing the mechanics of the turnover-pulse hypothesis with South African fossil data. Paleobiology $39,609-627$. 
Faith, J.T., Potts, R., Plummer, T.W., Bishop, L.C., Marean, C.W., Tryon, C.A., 2012. New perspectives on middle Pleistocene change in the large mammal faunas of East Africa: Damaliscus hypsodon sp. nov. (Mammalia, Artiodactyla) from Lainyamok, Kenya. Palaeogeography, Palaeoclimatology, Palaeoecology 361-362, 84-93.

Faith, J.T., Tryon, C.A., Peppe, D.J., in press. Environmental change, ungulate biogeography, and their implications for early human dispersals in equatorial East Africa, in: Jones, S.C., Stewart, B.A. (Eds.), Africa from MIS 6-2: Population Dynamics and Paleoenvironments. Springer, New York.

Faith, J.T., Tryon, C.A., Peppe, D.J., Beverly, E.J., Blegen, N., 2014. Biogeographic and evolutionary implications of an extinct Late Pleistocene impala from the Lake Victoria basin, Kenya. Journal of Mammalian Evolution 21, 213-222.

Faith, J.T., Tryon, C.A., Peppe, D.J., Beverly, E.J., Blegen, N., Blumenthal, S., Chritz, K.L., Driese, S.G., Patterson, D., 2015. Paleoenvironmental context of the Middle Stone Age record from Karungu, Lake Victoria Basin, Kenya, and its implications for human and faunal dispersals in East Africa. Journal of Human Evolution 83, 28-45.

Faith, J.T., Tryon, C.A., Peppe, D.J., Fox, D.L., 2013. The fossil history of Grevy's zebra (Equus grevyi) in Equatorial East Africa. Journal of Biogeography 40, 359-369.

Farquhar, G.D., Ehleringer, J.R., Hubick, K.T., 1989. Carbon isotope districrimination and photosynthesis. Annual Reviews in Plant Physiology and Plant Molecular Biology 40, 503-537.

Feathers, J.K., Migliorini, E., 2001. Luminescence dating at Katanda: A reassessment. Quaternary Science Reviews 20, 961-966.

Fortelius, M., Solounias, N., 2000. Functional characterization of ungulate molars using the abrasion-attrition wear gradient: a new method for reconstructing paleodiets. American Museum Novitates 3301, 1-36.

Gabel, C., 1969. Six rockshelters in the northern Kavirondo shore of Lake Victoria. African Historical Studies 2, 205-254.

Garrett, N.D., Fox, D.L., McNulty, K.P., Faith, J.T., Peppe, D.J., Van Plantinga, A., Tryon, C.A., 2015. Stable isotope paleoecology of Late Pleistocene Middle Stone Age humans from the Lake Victoria basin, Kenya. Journal of Human Evolution 82, 1-14. 
Gasse, F., Chalié, F., Vincens, A., Williams, M.A.J., Williamson, D., 2008. Climatic patterns in equatorial and southern Africa from 30,000 to 10,000 years ago reconstructed from terrestrial and near-shore proxy data. Quaternary Science Reivews 27, 2316-2340.

Groucutt, H.S., Petraglia, M., 2012. The prehistory of the Arabian Peninsula: deserts, dispersals, and demography. Evolutionary Anthropology 21, 113-125.

Gunz, P., Bookstein, F.L., Mitteroecker, P., Stadlmayr, A., Seidler, H., Weber, G.W., 2009. Early modern human diversity suggests subdivided population structure and a complex out-of-Africa scenario. Proceedings of the National Academy of Sciences 106, 6094-6098.

Harvati, K., Stringer, C., Grün, R., Aubert, M., Allsworth-Jones, P., Folorunso, C.A., 2011. The Later Stone Age Calvaria from Iwo Eleru, Nigeria: Morphology and Chronology. PLoS One 6, e24024.

Helgren, D.M., 1997. Locations and landscapes of Paleolithic sites in Semliki Rift, Zaire. Geoarchaeology 12, 337-361.

Hiscock, P., Clarkson, C., Mackay, A., 2011. Big debates over little tools: ongoing disputes over microliths on three continents. World Archaeology 43, 653-664.

Ichikawa, M., 1980. The utilization of wild plant foods by the Suiei Dorobo in northern Kenya. Journal of the Anthropological Society, Nippon 88, 25-48.

Jenkins, K., Faith, J.T., Tryon, C.A., Peppe, D.J., Nightingale, S., Ogondo, J.A., Johnson, C.R., Driese, S., 2012. New Excavations of a Late Pleistocene Bonebed and Associated MSA Artifacts, Rusinga Island, Kenya. PaleoAnthropology 2012, A17.

Jochim, M., 1976. Hunter-gatherer Subsistence and Settlement: A Predictive Model. Academic Press, New York.

Johnson, T.C., Chan, Y., Beuning, K., Kelts, K., Ngobi, G., Verschuren, D., 1998. Biogenic silica profiles in Holocene cores from Lake Victoria: Implications for lake level history and initiation of the Victoria Nile, in: Lehman, J.T. (Ed.), Environmental Change and Response in East African Lakes. Kluwer Academic Publishers, Dordrecht, the Netherlands, pp. 75-88.

Johnson, T.C., Kelts, K., Odada, E., 2000. The Holocene history of Lake Victoria. Ambio 29, 2-11. 
Johnson, T.C., Scholz, C.A., Talbot, M.R., Kelts, K., Ricketts, R.D., Ngobi, G., Beuning, K., Ssemmanda, I., McGill, J.W., 1996. Late Pleistocene desiccation of Lake Victoria and rapid evolution of cichlid fishes. Science 273, 1091-1093.

Kendall, R.L., 1969. An ecological history of the Lake Victoria basin. Ecological Monographs 39, 121-176.

Kingdon, J., 1989. Island Africa: The Evolution of Africa's Rare Animals and Plants. Princeton University Press, Princeton.

Kingston, J.D., 2007. Shifting adaptive landscapes: Progress and challenges in reconstructing early hominid environments. Yearbook of Physical Anthropology 50, 2058.

Kite, G.W., 1981. Recent changes in level of Lake Victoria. Hydrological Sciences Bulletin 26, 233-243.

Kite, G.W., 1982. Analysis of Lake Victoria levels. Hydrological Sciences Journal 27, 99-110.

Kwekason, A., Chami, F., 2003. The archaeology of Muleba, south west of Lake Nyanza: A preliminary report, in: Chami, F., Pwiti, G., Radimilahy, C. (Eds.), Climate Change, Trade and Modes of Production in Sub-Saharan Africa. Dar es Salaam University Press, Studies in the African Past No. 3, Dar es Salaam, pp. 59-85.

Lahr, M.M., Foley, R., 1998. Towards a theory of modern human origins: Geography, demography, and diversity in recent human evolution. Yearbook of Physical Anthropology 41, 137-176.

Lane, P., Ashley, C., Oteyo, G., 2006. New dates for Kansyore and Urewe wares from northern Nyanza, Kenya. Azania 41, 123-138.

Lehmann, T., 2009. Phylogeny and systematics of the Orycteropodidae (Mammalia, Tubulidentata). Zoological Journal of the Linnean Society, 649-702.

Levin, N.E., Cerling, T.E., Passey, B.H., Harris, J.M., Ehleringer, J.R., 2006. A stable isotope aridity index for terrestrial environments. Proceedings of the National Academy of Science USA 103, 11201-11205.

Lind, E.M., Morrison, M.E.S., 1974. East African Vegetation. Longman, London. 
Linder, H.P., de Klerk, H.M., Born, J., Burgess, N.D., Fjeldså, J., Rahbek, C., 2012. The partitioning of Africa: Statistically defined biogeographical regions in sub-Saharan Africa. Journal of Biogeography 39, 1189-1205.

Livingstone, D.A., 1976. The Nile: paleolimnology of headwaters, in: Rzóska, J. (Ed.), The Nile, Biology of an Ancient River. Dr. W. Junk B.V., The Hague, pp. 21-30.

Lorenzen, E.D., Heller, R., Siegismund, H.R., 2012. Comparative phylogeography of African savannah ungulates. Molecular Ecology 21, 3656-3670.

Louys, J., Faith, J.T., 2015. Phylogenetic topology mapped onto dietary ecospace reveals multiple pathways in the evolution of the herbivorous niche in African Bovidae. Journal of Zoological Systematics and Evolutionary Research 53, 140-154.

MacIntyre, S., Romero, J.R., Kling, G.W., 2002. Spatial-temporal variability in surface layer deepening and lateral advection in an embayment of Lake Victoria, East Africa. Limnology and Oceanography 47, 656-671.

Mackay, A., Stewart, B.A., Chase, B.M., 2014. Coalescence and fragmentation in the late Pleistocene archaeology of southernmost Africa. Journal of Human Evolution 72, 26-51.

Marean, C.W., 1997. Hunter-gatherer foraging strategies in tropical grasslands: Modelbuilding and testing in the East African Middle and Later Stone Age. Journal of Anthropological Archaeology 16, 189-225.

Masojć, M., 2010. First note on the discovery of a stratified Palaeolithic site from the Bayuda Desert (N-Sudan) within MAG concession. Mitteilungen der Sudanärchaologischen Gesellschaft du Berlin 21, 63-70.

McBrearty, S., 1981. Songhor: a Middle Stone Age site in western Kenya. Quaternaria 23, 171-190.

McBrearty, S., 1988. The Sangoan-Lupemban and Middle Stone Age sequence at the Muguruk site, western Kenya. World Archaeology 19, 379-420.

McBrearty, S., Brooks, A., 2000. The revolution that wasn't: A new interpretation of the origin of modern human behavior. Journal of Human Evolution 39, 453-563.

McDougall, I., Brown, F.H., Fleagle, J.G., 2005. Stratigraphic placement and age of modern humans from Kibish, Ethiopia. Nature 433, 733-736.

Mehlman, M.J., 1977. Excavations at Nasera Rock. Azania 12, 111-118. 
Mehlman, M.J., 1989. Late Quaternary Archaeological Sequences in Northern Tanzania. University of Illinois, Urbana.

Mellars, P., 2006. Why did modern human populations disperse from Africa ca. 60,000 years ago? A new model. Proceedings of the National Academies of Science USA 103, 9381-9386.

Milly, P.C.D., 1999. Comment on “Antiphasing between Rainfall in Africa's Rift Valley and North America’s Great Basin. Quaternary Research 51, 104-107.

Muli, J.R., 2005. Spatial variation of benthic macroinvertebrates and the environmental factors influencing their distribution in Lake Victoria, Kenya. Aquatic Ecosystem Health \& Management 8, 147-157.

Muli, J.R., Mavuti, K.M., 2001. The benthic macrofauna community of Kenyan waters of Lake Victoria. Hydrobiologia 458, 83-90.

Nelson, A., 2004. African Population Database.

Nenquin, J., 1967. Contributions to the Study of the Prehistoric Cultures of Rwanda and Burundi. Musee Royal de l'Afrique Centrale, Annales, Serie In- $8^{\circ}$, Sciences Humaines, No. 59, Tervuren, Belgium.

Nenquin, J., 1971. Archaeological prospections on the islands of Buvuma and Bugaia, Lake Victoria Nyanza (Uganda). Proceedings of the Prehistoric Society 37, 381-418.

Nicholson, S.E., 1996. A review of climate dynamics and climate variability in Eastern Africa, in: Johnson, T.C., Odada, E.O. (Eds.), The Limnology, Climatology and Paleoclimatology of the East African Lakes. Gordon and Breach Publishers, Netherlands, pp. 25-56.

Nicholson, S.E., 1998. Historical fluctuations of Lake Victoria and other lakes in the northern rift valley of East Africa, in: Lehman, J.T. (Ed.), Environmental Change and Response in East African Lakes. Kluwer Academic Publishers, Dordtrecht, pp. 7-35.

O'Brien, T.P., 1939. The Prehistory of Uganda Protectorate. Cambridge University Press, Cambridge.

Pearson, O., 2013. Hominin evolution in the Middle-Late Pleistocene: Fossils, adaptive scenarios, and alternatives. Current Anthropology 54, S221-S233.

Peters, J., 1990. Late Pleistocene hunter-gatherers at Ishango (Eastern Zaire): the faunal evidence. Revue de Paléobiologie 9, 73-112. 
Peters, J., 1991. Mesolithic fishing along the Central Sudanese Nile and the Lower Atbara. Sahara 4, 33-40.

Philipson, D., 1981. A preliminary archaeological reconnaissance of the Southern Sudan, 1977-8. Azania 16, 1-6.

Piper, B.S., Plinston, D.T., Barton, H., 1986. The water balance of Lake Victoria. Hydrological Sciences Journal 31, 25-37.

Posnansky, M., Reid, A., Ashley, C., 2005. Archaeology on Lolui Island, Uganda 1964-5. Anazia 40, 73-100.

Prendergast, M.E., 2010. Kansyore fisher-foragers and transitions to food production in East Africa: the view from Wadh Lang'o, Nyanza Province, Western Kenya. Azania 45, $83-111$.

Prendergast, M.E., Lane, P.J., 2010. Middle Holocene fishing strategies in East Africa: zooarchaeological analysis of Pundo, a Kansyore shell midden in Nothern Nyanza (Kenya). International Journal of Osteology 20, 88-112.

Reid, A., Njau, J.E.K., 1994. Archaeological research in the Karagwe District. Nyame Akuma 41, 68-73.

Reimer, P.J., Bard, E., Bayliss, A., Beck, J.W., Blackwell, P.G., Bronk Ramsey, C., Buck, C.E., Cheng, H., Edwards, L.E., Friedrich, M., Grootes, P.M., Guilderson, T.P., Haflidason, H., Hajdas, I., Hatté, C., Heaton, T.J., Hoffman, D.L., Hogg, A.G., Hughen, K.A., Kaiser, K.F., Kromer, B., Manning, S.W., Niu, M., Reimer, R.W., Richards, D.A., Scott, E.M., Southon, J.R., Staff, R.A., Turney, C.S.M., van der Plicht, J., 2013. IntCal13 and Marine13 radiocarbon age calibration curves 0-50,000 years cal BP. Radiocarbon 55, 1869-1887.

Rito, T., Richards, M.B., Fernandes, V., Alshamali, F., Cerny, V., Pereira, L., Soares, P., 2013. The First Modern Human Dispersals across Africa. PLoS One 8, e80031.

Robertshaw, P., 1991. Gogo Falls: A complex site east of Lake Victoria. Azania 26, 63196.

Robertshaw, P., Collett, D., Gifford, D., Mbae, N.B., 1983. Shell middens on the shores of Lake Victoria. Azania 18, 1-44. 
Roebroeks, W., 1988. From Find Scatters to Early Hominid Behavior: A Study of Middle Paleolithic Riverside Settlements at Maastricht-Belvédère (The Netherlands). University of Leiden, Leiden, the Netherlands.

Rose, J.I., Usik, V.I., Marks, A.E., Hilbert, Y.H., Galletti, C.S., Parton, A., Geiling, J.M., Fårn, V., Morley, M.W., Roberts, R.G., 2011. The Nubian Complex of Dhofar, Oman: An African Middle Stone Age Industry in Southern Arabia. PLoS One 6, e28239.

Rowan, J., Faith, J.T., Gebru, Y., Fleagle, J.G., 2015. Taxonomy and paleoecology of fossil Bovidae (Mammalia, Artiodactyla) from the Kibish Formation, southern Ethiopia: Implications for dietary change, biogeography, and the structure of the living bovid faunas of East Africa. Palaeogeography, Palaeoclimatology, Palaeoecology 420, 210-222. Scerri, E.M.L., 2013. The Aterian and its place in the North African Middle Stone Age. Quaternary International 300, 111-130.

Scerri, E.M.L., Drake, N.A., Jennings, R., Groucutt, H.S., 2014. Earliest evidence for the structure of Homo sapiens populations in Africa. Quaternary Science Reviews 101, 207216.

Scholz, C.A., Johnson, T.C., Cohen, A.S., King, J.W., Peck, J.A., Overpeck, J.T., Talbot, M.R., Brown, E.T., Kalindekafe, L., Amoako, P.Y.O., Lyons, R.P., Shanahan, T.M., Castañeda, I.S., Heil, C.W., Forman, S.L., McHargue, L.R., Beuning, K.R., Gomez, J., Pierson, J., 2007. East African megadroughts between 135 and 75 thousand years ago and bearing on early modern human origins. Proceedings of the National Academies of Science USA 104, 16416-16421.

Sene, K.J., Plinston, D.T., 1994. A review and update of the hydrology of Lake Victoria in East Africa. Hydrological Sciences Journal 39, 47-64.

Shahin, M., 1985. Hydrology of the Nile Basin. Elsevier, Amsterdam.

Sinclair, A.R.E., 1979. Dynamics of the Serengeti ecosystem: process and pattern, in: Sinclair, A.R.E., Norton-Griffiths, M. (Eds.), Serengeti: Dynamics of an Ecosystem. University of Chicago Press, Chicago.

Soares, P., Alshamali, F., Pereira, J.B., Fernandes, V., Silva, N.M., Afonso, C., Costa, M.D., Musilová, E., Macaulay, V., Richards, M.B., Černý, V., Pereira, L., 2012. The Expansion of mtDNA Haplogroup L3 within and out of Africa. Molecular Biology and Evolution 29, 915-927. 
Soper, R.C., Golden, B., 1969. An archaeological survey of Mwanza Region, Tanzania. Azania 4, 15-80.

Stager, J.C., 1984. The Diatom Record of Lake Victoria (East Africa): the Last 17,000 Years, in: Mann, D.J. (Ed.), 7th Diatom-Synposium.

Stager, J.C., Johnson, T.C., 2008. The Late Pleistocene desiccation of Lake Victoria and the origin of its endemic fauna. Hydrobiologia 596, 5-16.

Stager, J.C., Reinthal, P.N., Livingstone, D.A., 1986. A 25,000-year history for Lake Victoria, East Africa, and some comments on its significance for the evolution of cichlid fishes. Freshwater Biology 16, 15-19.

Stager, J.C., Ryves, D.B., Chase, B.M., Pausata, F.S.R., 2011. Catastrophic drought in the Afro-Asian monsoon region during Heinrich Event 1. Science 331, 1299-1302.

Stewart, K.M., 1989. Fishing sites of North and East Africa in the Late Pleistocene and Holocene: Environmental Change and Human Adaptation. British Archaeological Reports International Series, Oxford.

Sutcliffe, J.V., Petersen, G., 2007. Lake Victoria: derivation of a corrected natural water level series. Hydrological Sciences Journal 52, 1316-1321.

Talbot, M.R., Laerdal, T., 2000. The Late Pleistocene-Holocene paleolimnology of Lake Victoria, East Africa, based upon elemental and isotopic analyses of sedimentary organic matter. Journal of Paleolimnology 23, 141-164.

Talbot, M.R., Livingstone, D.A., 1989. Hydrogen index and carbon isotopes of lacustrine organic matter as lake level indicators. Palaeogeography, Palaeoclimatology, Palaeoecology 70, 121-137.

Talbot, M.R., Williams, M.A.J., Adamson, D.A., 2000. Strontium isotope evidence for late Pleistocene reestablishment of an integrated Nile drainage network. Geology 28, 343-346.

Temple, P.H., 1966. Evidence of Changes in the Level of Lake Victoria and Their Significance. Makerere University College, Kampala, Uganda.

Thiery, W., E.L., D., Panitz, H.-J., Demuzere, M., Lhermitte, S., van Lipzig, N., 2015. The Impact of the African Great Lakes on the Regional Climate. Journal of Climate, 4061-4085. 
Trauth, M.H., Maslin, M.A., Deino, A.L., Junginger, A., Lesoloyia, M., Odada, E.O., Olago, D.O., Olaka, L.A., Strecker, M.R., Tiedemann, R., 2010. Human evolution in a variable environment: the amplified lakes of Eastern Africa. Quaternary Science Reivews 29, 2981-2988.

Tryon, C.A., Crevecoeur, I., Faith, J.T., Ekshtain, R., Nivens, J., Patterson, D., Mbua, E.N., Spoor, F., 2015. Late Pleistocene age and archaeological context for the hominin calvaria from GvJm-22 (Lukenya Hill, Kenya). Proceedings of the National Academy of Sciences 112, 2682-2687.

Tryon, C.A., Faith, J.T., 2013. Variability in the Middle Stone Age of Eastern Africa. Current Anthropology 54, S234-S254.

Tryon, C.A., Faith, J.T., Peppe, D.J., Fox, D.L., Holt, K., Dunsworth, H., HarcourtSmith, W., 2010. The Pleistocene Archaeology and Environments of the Wasiriya Beds, Rusinga Island, Kenya. Journal of Human Evolution 59, 657-671.

Tryon, C.A., Faith, J.T., Peppe, D.J., Keegan, W.F., Keegan, K.N., Jenkins, K.H., Nightingale, S., Patterson, D., Van Plantinga, A., Driese, S., Johnson, C.R., Beverly, E.J., 2014. Sites on the landscape: Paleoenvironmental context of late Pleistocene archaeological sites from the Lake Victoria basin, equatorial East Africa. Quaternary International 331, 20-30.

Tryon, C.A., Peppe, D.J., Faith, J.T., Van Plantinga, A., Nightingale, S., Ogondo, J.A., Fox, D.L., 2012. Middle Stone Age artifacts and associated fauna from Rusinga and Mfangano islands, Lake Victoria, Kenya. Azania 47, 14-38.

Valcke, J., 1974. De Late Steentijd van de Munyamagrot op het eiland Buvuma in het Victorianyanzameer (Uganda). University of Ghent.

Van Damme, D., Van Bocxlaer, B., 2009. Freshwater molluscs of the Nile Basin, past and present, in: Dumont, H.J. (Ed.), The Nile: Origin, Environments, Limnology and Human Use. Springer, New York, pp. 585-629.

Van Noten, F., 1970. Wanneer begon de Afrikaanse Late Steentijd? Nieuwe data uit Uganda. Africa-Tervuren 16, 61-62.

Van Noten, F., 1971. Excavations at Munyama Cave. Antiquity 45, 56-58.

Van Noten, F., Haesaerts, P., Cahen, D., 1972. Un habitat Lupembien a Masango, Burundi: rapport préliminaire. Africa-Tervuren 18, 78-85. 
Vincent, A.S., 1985. Plant foods in savanna environments: A preliminary report of tubers eaten by the Hadza of northern Tanzania. World Archaeology 17, 131-148.

von Cramon-Taubadel, N., Lycett, S., 2008. Brief communication: Human cranial variation fits iterative founder effect model with African origin. American Journal of Physical Anthropology 136, 108-113.

Vrba, E.S., 1980. The significance of bovid remains as an indicator of environment and predation patterns, in: Behrensmeyer, A.K., Hill, A.P. (Eds.), Fossils in the Making. University of Chicago Press, Chicago, pp. 247-272.

Vrba, E.S., 1985. Environment and evolution: alternative causes of the temporal distribution of evolutionary events. South African Journal of Science 81, 229-236.

Wallace, I.A., Shea, J.J., 2006. Mobility patterns and core technologies in the Middle Paleolithic of the Levant. Journal of Archaeological Science 33, 1293-1309.

Wayland, E.J., 1925. Notes on a rapid geological survey of Buvuma Island. Annual Report of the Geological Survey Department for the year ended 31st December, 1925, 911.

Wayland, E.J., 1928. The possible disappearance of Lake Victoria. Annual Report of the Geological Survey Department for the year ended 31st December, 1927, 31-32.

White, F., 1983. The Vegetation of Africa, A Descriptive Memoir to Accompany the UNESCO/AETFAT/UNSO Vegetation Map of Africa. UNESCO, Paris.

Will, M., Mackay, A., Phillips, N., 2015. Implications of Nubian-Like Core Reduction Systems in Southern Africa for the Identification of Early Modern Human Dispersals. PLoS One 10, e0131824.

Worthington, S., Worthington, E.B., 1933. Inland Waters of Africa. The MacMillan Company, Boston.

Wrangham, R., Cheney, D., Seyfarth, R., Sarmiento, E., 2009. Shallow-water habitats as sources of fallback foods for hominins. Am. J. Phys. Anthropol. 140, 630-642.

Yellen, J.E., 1996. Behavioural and taphonomic patterning at Katanda 9: a Middle Stone Age site, Kivu Province, Zaire. Journal of Archaeological Science 6, 915-932.

Yellen, J.E., 1998. Barbed bone points: tradition and continuity in Saharan and subSaharan Africa. African Archaeological Review 15, 173-198. 
Yellen, J.E., Brooks, A.S., Cornelissen, E., Mehlman, M.H., Stewart, K., 1995. A Middle Stone Age worked bone industry from Katanda, Upper Semliki Valley, Zaire. Science 268, 553-556.

Yin, X., Nicholson, S.E., 1998. The water balance of Lake Victoria. Hydrological Sciences Journal 43, 789-811. 


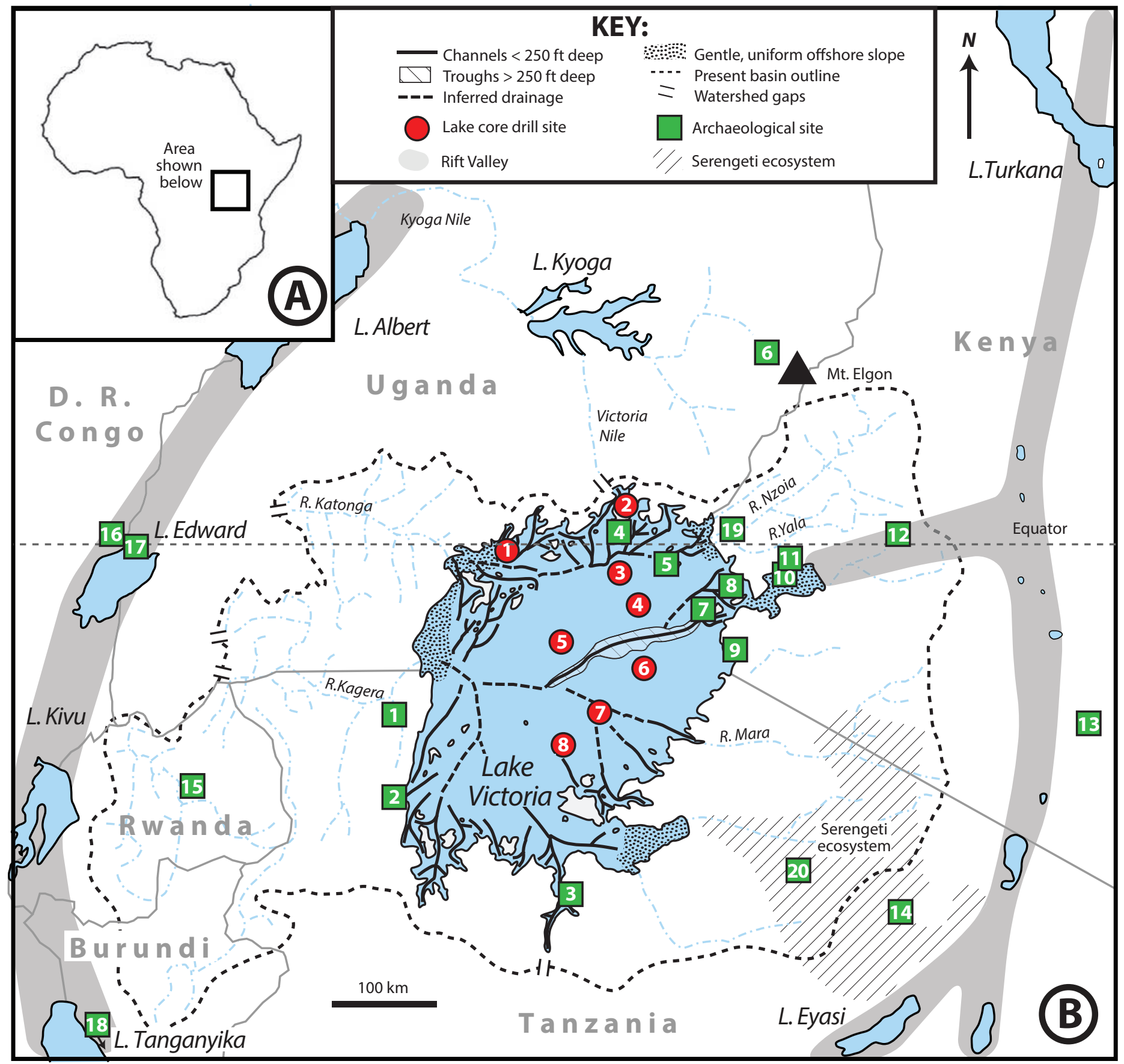

Figure 1 


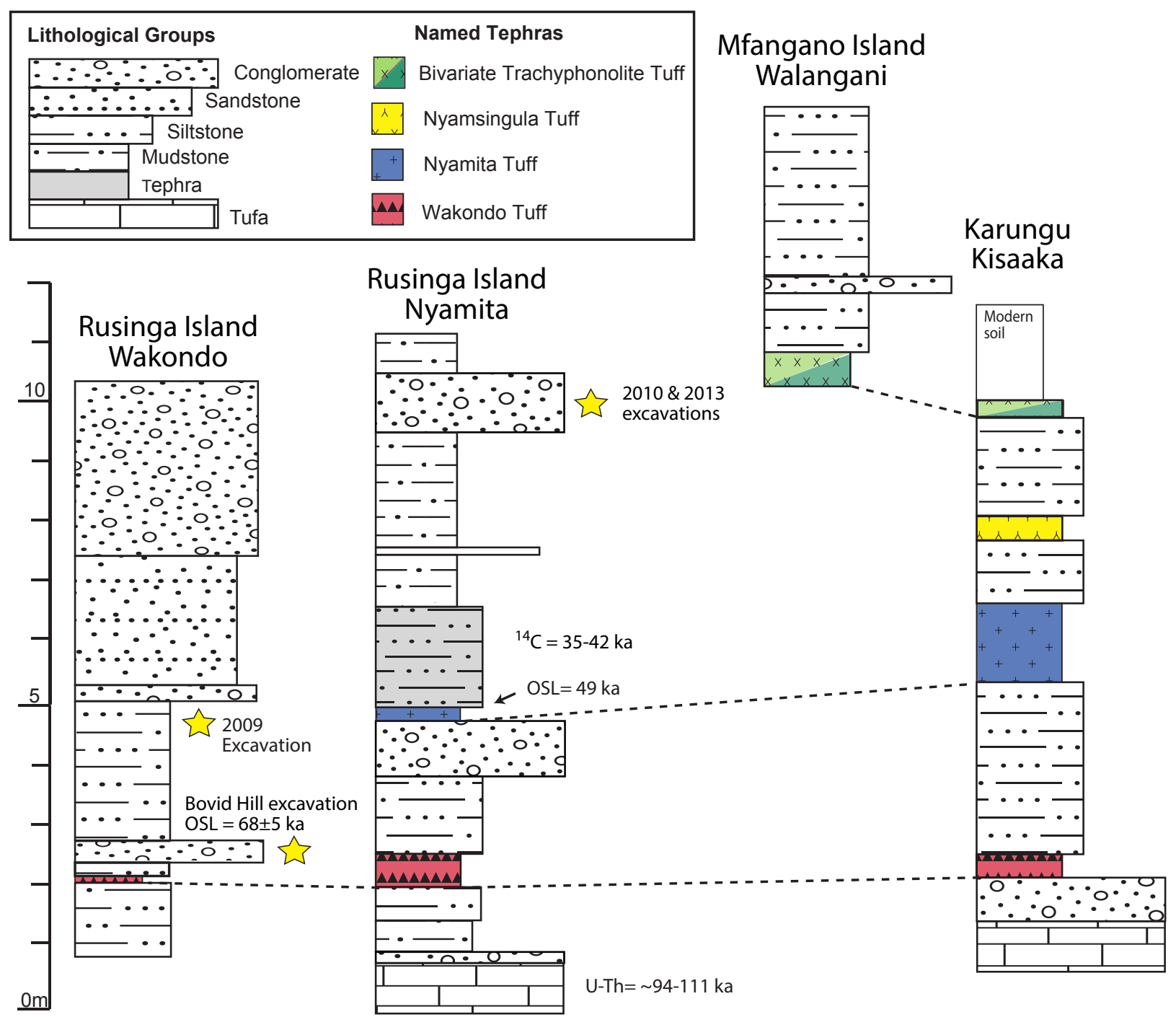

Figure 2 


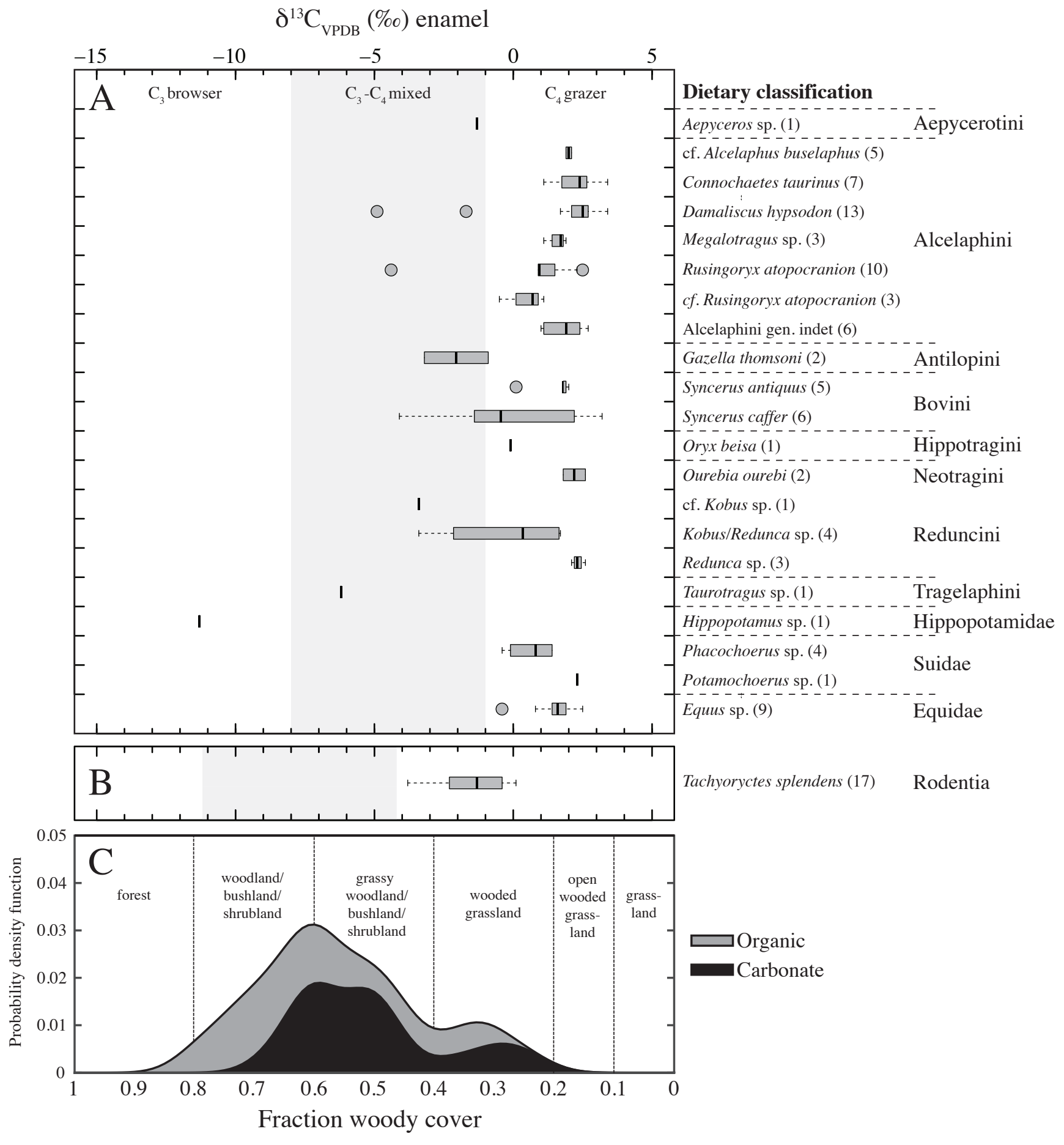

Figure 3 
Figure 4
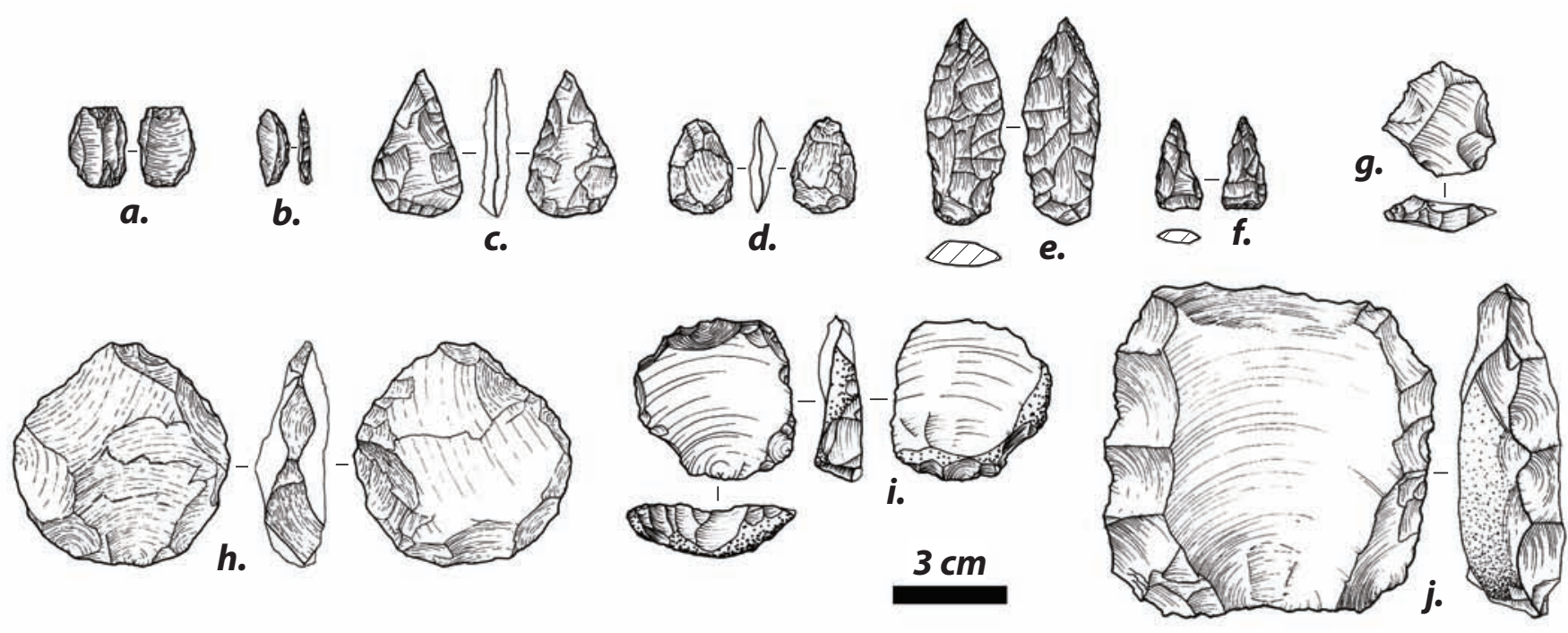


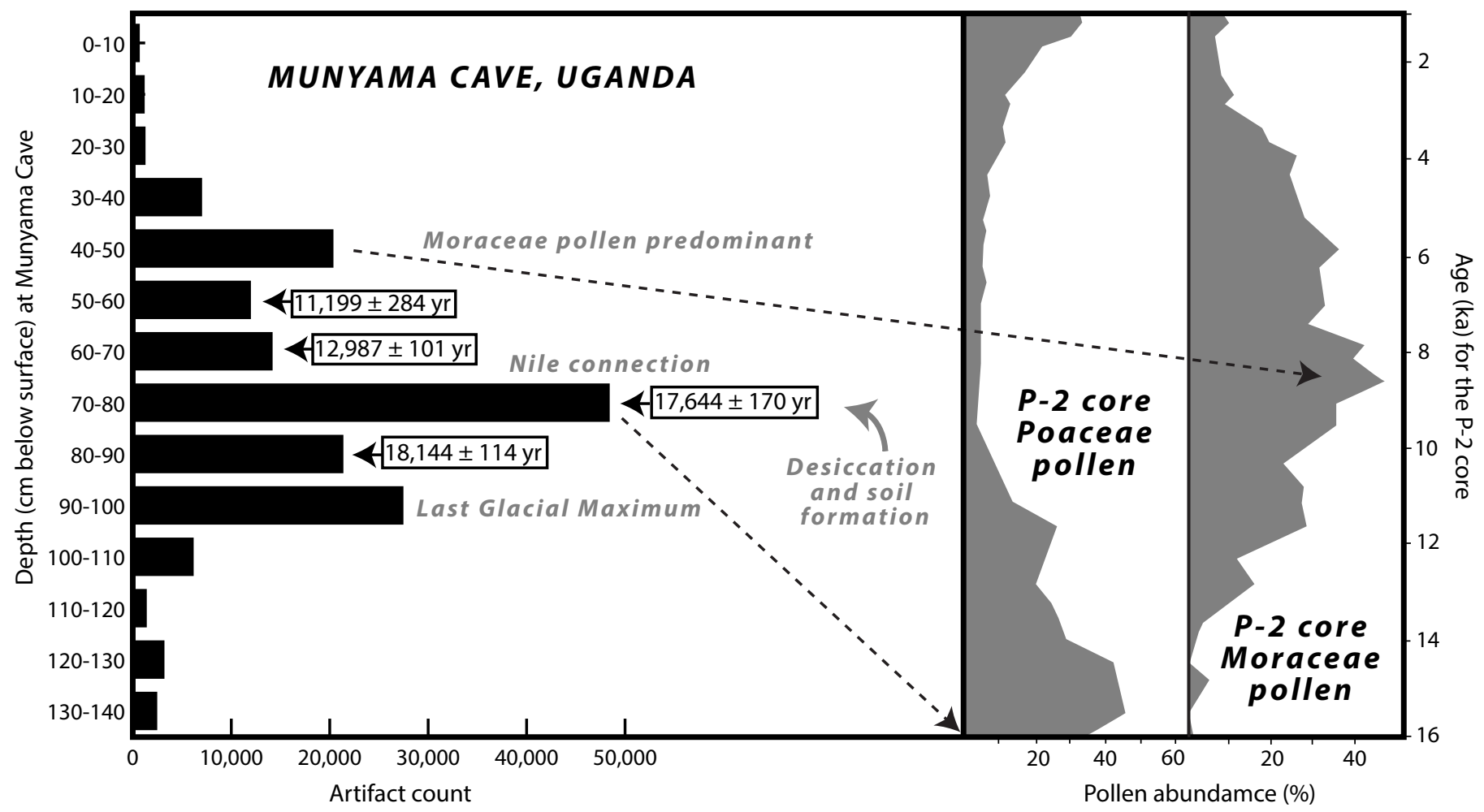

Figure 5 
Table 1. Specimen counts (NISP) for the mammalian fauna from Karungu, Mfanagno Island, and Rusinga Island.

\begin{tabular}{|c|c|}
\hline Tachyoryctes splendens & East African mole rat \\
\hline Otomys sp. & Vlei rat \\
\hline Lepus sp. & Cape hare \\
\hline Leporidae indet. & Indet. leporid \\
\hline Homo cf. sapiens & Homo cf. sapiens \\
\hline Papio sp. & Baboon \\
\hline Canis sp. & Jackal \\
\hline Crocuta crocuta & Spotted hyena \\
\hline Felidae cf. Caracal/Leptailurus & Caracal or Serval \\
\hline Panthera leo & Lion \\
\hline Panthera pardus & Leopard \\
\hline Orycteropus crassidenst & Extinct aardvark \\
\hline Procavia sp. & Hyrax \\
\hline cf. Loxodonta africana & African Elephant \\
\hline Ceratotherium cf. simum & White rhinoceros \\
\hline Diceros cf. bicornis & Black rhinoceros \\
\hline Rhinocerotidae indet. & Indeterminate rhino \\
\hline Equus quagga & Plains zebra \\
\hline Equus grevyi & Grevy's zebra \\
\hline Equus sp. & Indeterminate zebra \\
\hline Phacochoerus sp. & Warthog \\
\hline Potamochoerus sp. & Bushpig \\
\hline Kolpochoerus sp.t & Extinct bushpig \\
\hline Hippopotamus sp. & Hippo \\
\hline Taurotragus oryx & Eland \\
\hline Tragelaphus scriptus & Bushbuck \\
\hline Tragelaphus strepsiceros & Greater kudu \\
\hline Tragelaphus cf. imberbis & Lesser kudu? \\
\hline Tragelaphini indet. & Eland or kudu \\
\hline Oryx cf. beisa & Oryx \\
\hline Hippotragini indet & Oryx or roan/sable \\
\hline Redunca cf. arundinum & Southern reedbuck \\
\hline Reduncini sp. A & Kob or southern Reedbuck \\
\hline Redunca cf. redunca & Bohor reedbuck \\
\hline Redunca sp. B & Bohor reedbuck or Mountain reedbuck \\
\hline Reduncini indet. & Reduncini \\
\hline Alcelaphus buselaphus & Hartebeest \\
\hline Connochaetes taurinus & Wildebeest \\
\hline Damaliscus hypsodont & Extinct blesbok \\
\hline Megalotragus sp.t & Giant wildebeest \\
\hline Rusingoryx atopocraniont & Extinct wildebeest \\
\hline Alcelaphini indet. & Indeterminate Alcelaphine \\
\hline Gazella granti & Grant's gazelle \\
\hline Gazella thomsoni & Thomson's gazelle \\
\hline Antilopini indet. & Indeterminate Antelopine \\
\hline Aepyceros sp. novt & Extinct impala \\
\hline Syncerus antiquust & Long-horn buffalo \\
\hline Syncerus caffer & African buffalo \\
\hline Syncerus sp. & Indeterminate buffalo \\
\hline Ourebia ourebi & Oribi \\
\hline Oreotragus oreotragus & Klipspringer \\
\hline Madoqua sp. & Dik-dik \\
\hline Sylvicapra grimmia & Common duiker \\
\hline
\end{tabular}

\begin{tabular}{|c|c|c|}
\hline Karungu & Mfangano & Rusinga Island \\
\hline 11 & 0 & 10 \\
\hline 74 & 0 & 79 \\
\hline 3 & 1 & 2 \\
\hline 2 & 0 & 2 \\
\hline 0 & 0 & 1 \\
\hline 0 & 0 & 1 \\
\hline 0 & 0 & 1 \\
\hline 1 & 0 & 3 \\
\hline 1 & 0 & 0 \\
\hline 3 & 0 & 0 \\
\hline 1 & 0 & 0 \\
\hline 0 & 0 & 1 \\
\hline 0 & 1 & 0 \\
\hline 1 & 0 & 2 \\
\hline 7 & 0 & 3 \\
\hline 1 & 0 & 0 \\
\hline 0 & 1 & 0 \\
\hline 54 & 1 & 20 \\
\hline 24 & 0 & 10 \\
\hline 52 & 3 & 22 \\
\hline 24 & 1 & 15 \\
\hline 0 & 1 & 2 \\
\hline 0 & 0 & 1 \\
\hline 9 & 1 & 6 \\
\hline 4 & 0 & 2 \\
\hline 4 & 0 & 5 \\
\hline 0 & 0 & 1 \\
\hline 0 & 0 & 1 \\
\hline 2 & 0 & 0 \\
\hline 12 & 0 & 7 \\
\hline 1 & 0 & 2 \\
\hline 1 & 0 & 0 \\
\hline 4 & 2 & 35 \\
\hline 0 & 0 & 1 \\
\hline 1 & 3 & 15 \\
\hline 0 & 0 & 5 \\
\hline 26 & 3 & 23 \\
\hline 27 & 2 & 44 \\
\hline 39 & 2 & 64 \\
\hline 9 & 0 & 8 \\
\hline 69 & 12 & 329 \\
\hline 45 & 12 & 161 \\
\hline 1 & 0 & 2 \\
\hline 17 & 2 & 16 \\
\hline 2 & 0 & 0 \\
\hline 1 & 0 & 11 \\
\hline 11 & 3 & 8 \\
\hline 26 & 2 & 10 \\
\hline 1 & 1 & 7 \\
\hline 5 & 1 & 18 \\
\hline 0 & 1 & 0 \\
\hline 0 & 1 & 0 \\
\hline 0 & 1 & 9 \\
\hline
\end{tabular}

